\title{
Conceptual Model of Performance Measurement for Supply Chain Management: Value-Based Scorecard Approach
}

\author{
Mohamed Abdelmounem Serag \\ Assistant Professor in Accounting Department \\ Sadat Academy for Management Sciences
}

Address: Kingdom of Saudi Arabia, King Khalid University, College of Administration and Financial Sciences, ABHA, P.O. Box: 3247, Postal Code: 61471

Tel.+966593767651

Email: mohserag1970@yahoo.com 


\section{نموذج مفاهيمي لقياس أداء سلاسل التوريد: مدخل قياس الآداء المتوازن علي أساس القيمة}

\section{ملخص}

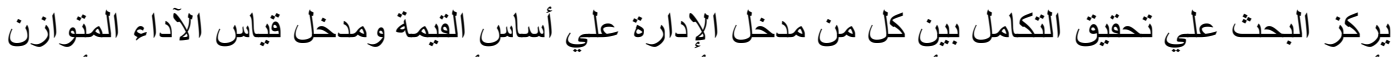

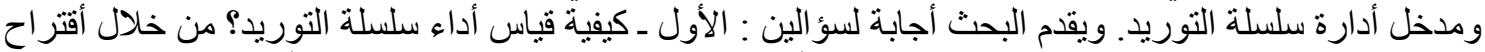

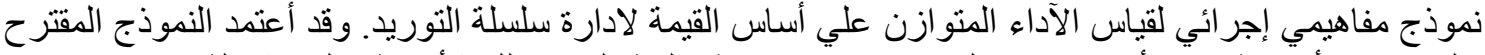

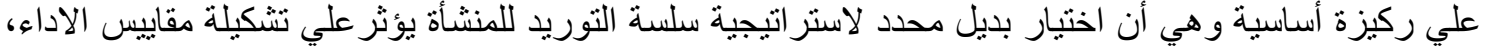

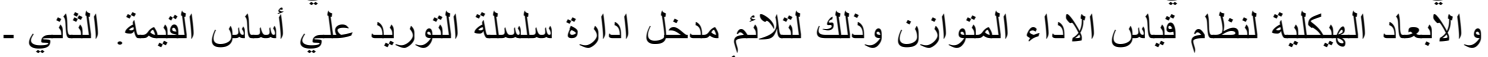

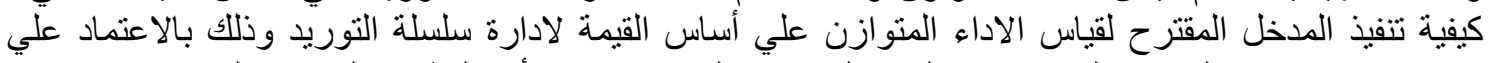

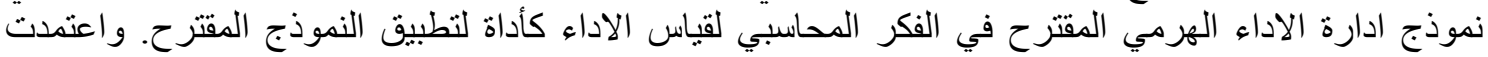

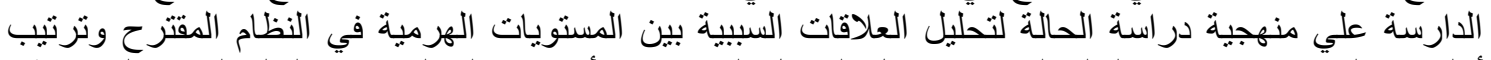

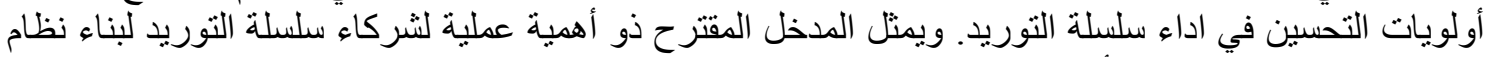

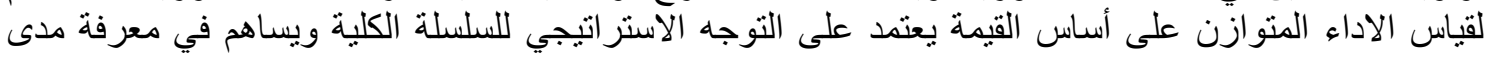
مساهمة كل شريك في السلسلة الى القيمة الكلية لسلسة التوريد.

المصطلحات الرئيسية :ادارة سلسلة التوريد، الإدارة على أساس القيمة، نظام قياس الأداء المتوازن على أساس القيمة، در اسة حالة عملية. 


\title{
Conceptual Model of Performance Measurement for Supply Chain Management: Value-Based Scorecard Approach
}

\begin{abstract}
This paper offers an integrative view of value-based management (VBM) and the balanced scorecard (BSC) and supply chain management (SCM). The work answers two research questions. First, what do I measure? By presenting a conceptual model for SCM value-based scorecard consists of sequential steps with the outcomes for each step leading to naturally to the next step. In developing the model, various aspects of SC value added strategy could be expected to affect the specific mix of measures used and structural changes of balanced scorecard perspectives to fit the needs of value-based SCM. Second, how do I implement SCM value-based scorecard? By using a pyramid performance management model as a tool that can lead to the actual application of SCM value-based scorecard approach. The study uses a case-oriented example to analyze the causal relationships between the levers of the hierarchy of SCM value-based scorecard. The proposed approach in this study is called the design-oriented approach in management control literature. It is useful for all SC members to make out value-based scorecard based on strategic themes from the view of the total supply chain because each member can know how it can contribute to the total value of supply chain.
\end{abstract}

Keywords: supply chain management; value-based management; value-based scorecard; case-oriented example. 


\section{Introduction}

Creating and sustaining shareholder value, not just accounting profit, top the list of priorities in many modern companies, are pivotal in strategic sourcing decisions and reflect the credibility of corporate governance systems (Monden 2006)(Rappaport 1996). To affect the shareholder value objective, new concepts, and management models such as supply chain management models (SCM), balanced scorecard (BSC), and value-based management (VBM) have emerged in the last decade or so (Faupel 2012). In management theory, the three concepts occasionally described an integrating business philosophy. This paper offers an integrative view of value-based management (VBM) and the balanced scorecard (BSC) and supply chain management (SCM). The resulting "SCM value-based scorecard" incorporates the value-based business philosophy in SCM by creating a link between the BSC and SCM, and also a link between BSC and the "value-added" corporate strategy.

The integrative approach of SCM to achieve and sustain shareholder value by the triple-A supply chain makes balanced scorecard approach indispensable for effective SCM, particularly since maximizing firm value currently preoccupy many leading companies (Lee 2000,2004).

There is currently great interest among researchers and senior managers in balanced scorecard (BSC) performance measurement systems. The commonalities between the two concepts as well as the need for performance measurement of SCM activities justify the discussion of how the BSC can be integrated into SCM to satisfy the goal of maximizing shareholder value (Brewer and Speh 2000,2001).

Apart from the prominence of the two concepts, there is anther very convincing reason: from a theoretical view, the supply chain regarded as a virtual business entity to which the BSC performance measurement system could be applied analogs to the company. However, even at this point, it can be stated that this idealistic view reduced to a more practical perspective (Ackermann 2007). Successfully executed, a BSC approach to SCM will bring new levels of operating efficiencies and market response to all of the supply chain partners.

On the other side, the challenge for many companies is that the alignment of value-based performance measurement between all the firms in the supply chain is still rather weak (Yücesan 2016).

The main reason for this is that supply chain performance metrics, and value-based performance metrics define in different ways which create difficulty in translating supply chain operational measures with their focus

192 
on day-to-day operations into value targets (Otto and Obermaier 2009; Elgazzar et al. 2012).

SC performance metrics measure the performance of SC processes in terms of reliability, responsiveness, agility, cost, and asset management based on supply chain operations reference model (SCOR) using standard metrics. While value drivers (drivers of value creation) measure and analyze the performance of the outputs of these processes in terms of sales growth, operating cost reduction, and efficiency of capital (fixed and working) using EVA ratio analysis (Presutti and Mawhinney 2007). So the value-based metrics are designed to make the value-added measurable in a context of SCM.

Besides that, managers in SCM responsible for implementing VBM often do not fully understand the concept (Riceman et al. 2002). Therefore, one of the main issues that companies frequently confronted with is the lack of knowledge of the factors that ultimately create value added (Jensen 2002). In other words, while the objective of creating value-added is quickly defined, achieving that objective continues to be an immense problem for SCM. To solve this issue, enabling the universal implementation of value-based management require a tool (Tyndall et al. 1998). A strategic accounting is a management tool that, with some modifications seems to fit the bill is the balanced scorecard.

It appears that one single performance indicator such as the EVA is not enough to achieve all the objectives of an overall value-based SCM philosophy Yücesan (2007). In fact, a metric system able to support the target value-added in the long term by identifying, quantifying, and accounting future value drivers (Young and O'Byrne 2001). The SCM value-based scorecard suggested in this paper seems to be able to meet these requirements.

Some new scorecard approaches that attempt to include the value-based framework have already been developed in business practice (Ittner and Larcher 2001) but lack a theoretical background of how to apply it in SCM environment.

This paper answers two research questions concerning SCM value-based performance measurement. First, what do I measure? By presenting a conceptual model for SCM value-based scorecard. It provides an overarching template that can guide the value-based metrics selection process in SCM. Second, how do I implement SCM value-based scorecard? By using of tools that can help support the implementation of the new measurement approach. The tools cannot be limited to the measurement 
system itself, they also need to include strategic trade-off and planning frameworks in order to assure executive "buy-in" and commitment and initiate actual improvement processes in the supply chain. The paper uses a pyramid performance management model suggested by (Lynch and Cross 1995, Hofman 2004,2007) as a tool to develop what we call a hierarchy of SCM value based metrics constructing a crucial final step leading to the actual application of a new measurement approach. This would make the proposed conceptual model more useful in providing additional information to the decision makers. The paper adopts a case-oriented example to highlight the value of using the hierarchy of value-based scorecard metrics in practice.

The paper divided into four main sections, the first section after introduction gives a review of the state of the art value-based performance measurement in SCM and hypotheses development. The second section includes a suggested conceptual model for the supply chain value-based scorecard. The third section includes a case-oriented example. Finally, conclusions are drawn and some suggestions for future research are outlined.

Due to their prominence, the fundamental of all concepts of SCM, VBM, and the BSC will not describe in the paper.

\section{The state of the art value-based performance measurement in SCM}

\section{2-1 Literature review}

There are some conceptual frameworks for SCM value-based performance measurement that are proposed by different research papers for the last ten years. Nine papers on value-based performance measurement for SCM are reviewed to illustrate the variety of research directions in this area. The selected manuscripts also provide a basis for the positioning of this paper to current research. An overview of selective literature indicating the heterogeneity of SCM concepts, VBM approach, concepts, and value drivers in SCM, and research method as is depicted and briefly interpreted in Table (1).

(Christopher and Ryals 1999) Propose a conceptual framework that based on the strategic perspective of SCM which comprehended as the coordination of all logistics activities encompassing the management of physical and logical flows in a network of organizations linked by processes producing products and services that add value to the final consumer. The perceiving financial value created for shareholders, most often measured by EVA, as returns that exceed the investors' total cost 
including risk premiums, the authors apply the definition of VBM as a concept to maximize long-term value creation with a managerial focus on the four SC- related value drivers, namely (i) revenue growth, (ii) operating cost reduction, (iii) working capital efficiency and (iv) fixed asset efficiency.. Furthermore, several industrial case examples are cited to illustrate the value creation potential of product availability, supplier integration, postponement strategies or integrated product design.

Based on the assumption that logistics create shareholder value by impacts on cash, invested capital or cost of capital, (Walters 1999) develops conceptual model to link EVA with options for logistics decision making. The proposed framework brings strategic and operational management criteria and value drivers in the context of logistics activities to shareholder value. This framework substantiated by stating that strategic value drivers have a direct impact on shareholder value while operational value drivers, especially sales growth rate, operating profit margin and income tax rate, are influenced by operating decisions during strategy implementation. Furthermore, investment decisions affect the structure of fixed and working capital. Based on these conclusions, shareholder value planning is related to the management of productivity, strategic cash flow, profitability, and investments, and logistics activities are assigned to each of these managerial areas. The case example of a fictitious manufacturing company for industrial durable goods illustrates how logistics decision making can positively influence EVA.

Six different concepts to measure value impacts stemming from logistics are discussed by (Lambert and Burduroglu 2000). The assessed concepts range from customer satisfaction as being the least quantitative to shareholder value identified as the most comprehensive financial measure.

The authors base their explanation on the value drivers explained by Rappaport (1996) and provide qualitative arguments to validate the finding of Christopher and Ryals (1999) that logistics affect shareholder value by influencing revenue, operating cost, working capital, and fixed assets.

The conceptual framework suggested by (Lambert and Pohlen 2001) links SC strategy and corporate performance to operational efficiency. In this approach, an SC is perceived as an inter-organizational multi-level network comprising a focal company with various tiers of customers and suppliers that are linked by eight SC-related processes. The basic idea of this framework intends to gradually evaluate and align the profitability of all customer and supplier interfaces in this network beginning with a focal company. This approach aims at maximizing the shareholder value, measured by EVA, for the total SC and each of its members. In an 
explanatory numerical analysis of a fictitious company, the authors illustrate the relevance of the SC position and the actual performance level for value creating inventory optimization.

Based on the SC hypothesis that SCM improves the profitability of a firm, (Möller 2003) designs a conceptual framework for value-based SCM. The author comprehends SCM as the planning, steering, and control of physical, logical, financial and service-related flows through intra-and inter-organizational networks which are characterized by the focal or polycentric allocation of power to improve efficiency and effectiveness. In this paper, it is stated that operational and strategic planning dimensions have to be integrated in order to achieve value-related targets on the company or network level. The author proposes a conceptual model consisting of five levels to meet this integration.

(Lasch et al. 2006) state that VBM grounded on financial correlation between value drivers and company value has to consider. A conceptual model is designed to outline the impacts of logistics performance on company targets. Efficiency and effectiveness of logistics contribute to the profitability of a company, competitive advantages arising from logistics performance ensure the economic future of a firm and customer satisfaction. In this paper, four value drivers - sales growth, profit margin, investments and cost of capital arc related to the core strategies of cost leadership and differentiation.

A further conceptual model for value-based performance management is outlined by (Losbichler and Rothböck 2006). The model grounded on the perception that SCM comprehended as the end-to-end integration of value-adding business processes which affects growth, profitability, and capital of a company and thus its financial performance measured by EVA. The assessment of these effects comprises five steps. Firstly value gaps are identified, e.g. by applying benchmarking, which Secondly mapped to SC processes and strategy. In a third step, relavent SCM tools to bridge these gaps are identified and ranked. Appropriate projects to realize the identified optimization potential are defined in the fourth step, which followed by the assessment of resulting business cases. The authors conclude that the integration of SCM and shareholder value facilitates the identification of value gaps and the inception of SC initiatives that contribute to company value.

A conceptual framework for value-based SC performance management is designed and empirically tested by (Hofmann and Locker 2009). The authors comprehend an SC as a network of different firms that are linked via planning, sourcing, manufacturing and delivery processes as well as 
physical and logical flows and that strive for efficiency and effectiveness to benefit from performance and customer achievements. This frame matches operational SC performance indicators to company value, measured by EVA and its components sales, cost, and capital, via value drivers that are assessed and weighted by magnitudes, sensitivities and changes of financial and non-financial figures. The concept is tested in a case example from the packaging industry. Limitations of this approach arise from the circumstance that only selected performance aspects evaluated and incorporated into the EVA calculation. In particular, long-term sales effects of SC flexibility and customer satisfaction are not incorporated into the approach. Furthermore, interactions between assessed indicators and applied metrics neglected.

A framework designed by Otto and Obermaier (2009) is suitable to structure and reveal the impacts of SC network investments on firm value. The authors state that the complexity of inter-organizational SC networks comprising physical, logical and financial flows as well as social and institutional relationships prevents from quantifying SC value on the network level. Instead, the authors focus on firm value as primary managerial objective measured by discount cash flow (DCF) or residual income and differentiate five components in the suggested framework to assess value impacts.

The first component considers the dimensions of networking given by the flows and relationships within the network. Mechanisms of networking causing variations of arcs, frequency, and objects constitute the second component. Effects of networking, i.e. processes, behavior, and resources represent the third component. The nonfinancial quantification of networking, categorized as the fourth component, reflects aspects of efficiency and effectiveness as well as power, innovation or uncertainties. The fifth component, dealing with the financial quantification of networking, incorporates sales, cost, taxes, capital and cost of capital. The Framework integrates financial and SC aspects, but limited by shortened applicability to managerial practice or the restricted possibility of empirical testing. 


\begin{tabular}{|c|c|c|c|c|}
\hline Paper & SCM approach & Value metric & Value drivers & Research method \\
\hline $\begin{array}{l}\text { Christopher } \\
\text { and Ryals } \\
\text { (1999) }\end{array}$ & $\begin{array}{l}\text { Company networks } \\
\text { with internal } \\
\text { processes and } \\
\text { external interfaces }\end{array}$ & $\begin{array}{l}\text { Shareholder value, } \\
\text { EVA }\end{array}$ & $\begin{array}{l}\text { Sales, cost, working } \\
\text { capital, fixed assets }\end{array}$ & Conceptual model \\
\hline Walters (1999) & $\begin{array}{l}\text { Logistics } \\
\text { Management }\end{array}$ & $\begin{array}{l}\text { Shareholder value, } \\
\text { EVA }\end{array}$ & $\begin{array}{l}\text { Logistics-related } \\
\text { activities }\end{array}$ & Conceptual model \\
\hline $\begin{array}{l}\text { Lambert and } \\
\text { Burduroglu } \\
(2000)\end{array}$ & $\begin{array}{l}\text { Functional } \\
\text { (Logistics) }\end{array}$ & $\begin{array}{l}\text { Shareholder value as } \\
\text { most comprehensive }\end{array}$ & $\begin{array}{l}\text { Profitability and } \\
\text { capital efficiency }\end{array}$ & $\begin{array}{l}\text { Comparison of six } \\
\text { qualitative concepts }\end{array}$ \\
\hline $\begin{array}{l}\text { Lambert and } \\
\text { Pohlen (2001) }\end{array}$ & $\begin{array}{l}\text { Eight cross-company } \\
\text { processes add } \\
\text { customer and } \\
\text { stakeholder value }\end{array}$ & $\begin{array}{l}\text { Shareholder value, } \\
\text { EVA }\end{array}$ & $\begin{array}{l}\text { Customer and } \\
\text { supplier } \\
\text { profitability }\end{array}$ & $\begin{array}{l}\text { Conceptual model, } \\
\text { illustrative numerical } \\
\text { example }\end{array}$ \\
\hline Möller (2003) & $\begin{array}{l}\text { Intra-and inter- } \\
\text { organizational } \\
\text { networks } \\
\text { management of } \\
\text { physical. Logical, } \\
\text { financial and service }\end{array}$ & $\begin{array}{l}\text { SC network value } \\
\text { added }\end{array}$ & $\begin{array}{l}\text { Intangible and } \\
\text { tangible value } \\
\text { (profitability, cost } \\
\text { of capital) }\end{array}$ & Conceptual model \\
\hline $\begin{array}{l}\text { Lasch et al. } \\
(2006)\end{array}$ & Functional (logistics) & Company value & $\begin{array}{l}\text { Effectiveness, } \\
\text { efficiency, } \\
\text { competitive } \\
\text { advantage, customer } \\
\text { orientation }\end{array}$ & Conceptual model \\
\hline $\begin{array}{l}\text { Losbichler and } \\
\text { Rothböck } \\
(2006)\end{array}$ & Company internal SC & $\begin{array}{l}\text { Shareholder value, } \\
\text { EVA }\end{array}$ & SC performance & Conceptual model \\
\hline $\begin{array}{l}\text { Hofmann and } \\
\text { Locker (2009) }\end{array}$ & $\begin{array}{l}\text { Inter-organizational } \\
\text { management of flows } \\
\text { of goods and } \\
\text { information }\end{array}$ & $\begin{array}{l}\text { Shareholder value, } \\
\text { EVA }\end{array}$ & $\begin{array}{l}\text { Sales, cost, capital, } \\
\text { operational drivers }\end{array}$ & $\begin{array}{l}\text { Conceptual model, } \\
\text { case example }\end{array}$ \\
\hline $\begin{array}{l}\text { Otto and } \\
\text { Obermaier } \\
(2009)\end{array}$ & $\begin{array}{l}\text { Inter-organizational } \\
\text { Network }\end{array}$ & $\begin{array}{l}\text { Company value. } \\
\text { DCF }\end{array}$ & $\begin{array}{l}\text { SC network } \\
\text { investments }\end{array}$ & Conceptual model \\
\hline
\end{tabular}

Table (1) SCM value-based measurement in selected research papers

(Source: adapted from (Brandenburg 2013, pp.48-49) 


\section{2-2 Research gap and hypotheses development}

Table (1) tries to present differences and similarities between the conceptual frameworks for value-based measurement in SC based on some criteria that are clearly interdependent and enable an identification of each model's characteristics. The closer study of these works reveals that:

1-SCM approach in the suggested models in a literature categories according to two types. The first type geared towards an internal analysis of companies, which mainly incorporate organizational performance measurements. Measuring the performance of domestic supply chains or how things are working out with proximity partners is important, but insufficient since it only accounts for the individual performance of each link in the chain separately, without focusing on linkages between different supply chain partners. The second category includes models that have an extensive overview of the supply chain, viewing it as something ranging from supplier's suppliers to customer's customers and incorporating the financial, organizational and societal aspects of performance. Firms of this kind are integrated into a complex network of inter-company relationships and want to raise performance by pursuing an extended interorganizational, multi-chain or societal vision (Baurratt 2004). Both authors (Anderson et al. 2007) set seven principles of supply chain management. The authors argued that, if applied collectively, these principles could enable supply chain partners to enhance revenue, control costs, increase asset utilization, and improve customer satisfaction. The seventh principle stated that supply chains needed to "adopt channel spanning performance measures to gauge collective success in reaching the end user effectively and efficiently."

Indeed, most business managers would agree in theory, that such measures are needed to motivate the type of inter-organizational collaboration that is necessary to satisfy end customers (Gunasekaran et al. 2001; Gunasekaran et al. 2004; Gunasekaran and Kobu 2007)(Ramanath et al. 2011). They would be quick to point out that they work in the world of reality, not theory. The challenge is to close the gap between the general appeal of chain-spanning measures and the genuine concerns that complicate their actual usage (Jack 2011).

Closing the gap requires a performance measurement system that is entirely different from those applied in traditional logistics, operations, and purchasing environments (Shepherd and Gunter 2006). In these areas, the focus is on measuring efficiency and effectiveness within functions and within the sub-activities of those functions. Both the function wide performance measures and the specific activity-focused measures are 
necessary in tracking and controlling how well the system is performing and how competent managers are in executing their key functional responsibilities.

The methodology in the paper emphasis on the concept of how well a group of companies shows regarding value creation for the customers and shareholders. In order to direct the SCM activities towards value creation question have to be answered: how can SCM means and activities be directed towards strong firm value? So, the performance measurement philosophy in the paper adopted three principles. First, companies in the supply chain must work collaboration and the supply chain performance measurement should reflect this. According to the study of Yücesan (2016) VBM based SCM has two inter-wined dimensions: on the one hand, VBM should enable value creation through the three-dimensional concurrent engineering (3D-CE): the simultaneous design of the product, of the process, and of the supply chain. While value creation by a firm is necessary, it does not automatically ensure value capture by the same firm. Value capture, on the other hand, focuses on the coordination of the firms within the supply chain. Second, alignment of independent partners is the primary challenge in supply chain coordination, including the design and implementing of collaborative practices. The performance measurement process must be structured to provide incentives for cooperative behavior. Third, each firm in the supply chain, regardless of how far upstream or downstream it may be, needs to focus on the satisfaction and ultimate cost of serving the final customer. Indeed, the rationale for adopting VBM based SCM is to reduce costs, increase the speed to market, and add the most value for the ultimate customer. Therefore, we developed the following hypothesis:

$H_{1}$ : VBM based SCM approach has a positive impact on collaboration, alignment, and firm value.

2- VBM approach most often linked to EVA and shareholder value. Despite the widespread application of EVA as a performance metric, the effectiveness, and appropriateness of this method, as with many ratio-based measures, is questioned (Biddle et al. 1999; Christopher and Ryals (1999); Stewart 2009; Ellinger et al. 2012)). (Brewer et al. 1999) Note that EVA has some limitations including lack of control for firm size differences, financial orientation, and short-term orientation. Also, (Srivastava et al. 1999) points out that the metric is criticized for its under-valuation of growth potential and intangible assets. EVA has new limited utility for making accurate comparisons between firms since it is relatively susceptible to manipulation. 
EVA Momentum, a new metric developed by EVA Dimensions in 2009 eliminates many of the limitations associated with EVA and other profit measures to better enable direct comparisons between firms' ability to generate shareholder value (Stewart 2013). EVA Momentum is a ratio of the change in firms EVA divided by a prior period's sales. Stewart (2009) identifies six ways in which EVA Momentum addresses problems associated with conventional financial data based ratios. First, EVA Momentum incorporates EVA in its calculation and is therefore also a measure of economic profit or the creation of shareholder value. Second, because the calculation includes trailing period sales, EVA Momentum is a financial measure that managers can maximize with less risk of generating potentially misleading information. Third, by creating a ratio that incorporates EVA and prior period sales, EVA Momentum produces a standardized ratio that can be appropriately used to compare firms to one another or overall industry averages. Fourth, EVA Momentum is less likely to be manipulated or "gamed" because the metric takes into account prior period sales along with the traditional EVA calculation. EVA momentum allows to measuring the change in economic profit over time rather than just taking a snapshot of a level of economic profit at a single point in time. Stewart (2013) describes this as making the EVA momentum metric "situation neutral." Fifth, the EVA momentum metric is market-calibrated with a true zero point. If a firm's EVA Momentum is zero, the firm is doing exactly what investors expect (i.e. meeting expected return or investments). Thus unlike other financial metrics that tend to be arbitrary, EVA Momentum has a consistent break-even point. Positive EVA Momentum indicates the firms are doing better than expected while negative EVA Momentum suggests it is doing worse. Finally, the zero-point characteristic serves as an early warning system that managers can use to see if their organizations are meeting shareholder expectations.

Due to the standardization of EVA Momentum, managers can quickly determine whether their firms are creating an acceptable level of shareholder value. Because the combination of growing sales and an excellent or improving EVA is the extremely rare basis of high financial performance, the current research choices the EVA Momentum metric as a measure of shareholder value. This led to the following hypothesis:

$\mathrm{H}_{2}$ : The positive influence of VBM based SCM on shareholder value is measured by EVA Momentum.

3-A proposed model adopted the value orientation concept that provides the framework in which the scorecard is implemented in SCM. The scorecard adopted to produce a system consisting of the main indicators 
connected by causalities functions as the means to put value orientation into practice. The problematic implementation of value orientation in business practice should emphasis at this point. The value-based scorecard enables managers to realize the link between value-based corporate strategy and supply chain performance while connecting supply chain metrics (value-based scorecard for supply chain) with the value-based SC strategy. The paper based on the linkage between VBM based SCM approach and shareholder value is mediated by SC value-based scorecard. Therefore, the following hypothesis was proposed:

$H_{3}$ : The positive influence of VBM based SCM on shareholder value is mediated through SC value-based scorecard.

Value drivers in SCM range from a single function, operational SC activities, and processes to SC strategy. Underlying value drivers are the solution to the determinants of implementing value-based metrics at the divisional level (Dekker et al. 2012). The measurement of selected value drivers at the divisional level should be complementary to value-based measures at global or group level and remove the need to calculate divisional cost of capital. Selected value drivers should incorporate as part of a balanced scorecard approach. Thus, we propose that at supply chain level, if these measures are to be introduced, they may be presented most successfully regarding those value drivers that are consistent with maximizing shareholder value for the supply chain as a whole and this could be within an adapted "value-based scorecard" framework. The criticism of managing complicated SCM with just one single performance indicator is offset by the proposed value-based scorecard approach. Enabling managers on lower functional levels to see the impact their actions have on the company value.

Nevertheless, it must also acknowledge that the BSC is a hierarchical approach to performance measurement that does not readily support the process-oriented concept of SCM. It is, therefore, worthwhile to use a tool that can help support the implementation of the new measurement approach. This paper uses a pyramid performance management model as a tool to construct a hierarchy of SCM value-based metrics. Therefore, a more comprehensive and holistic construct is needed to select performance measures for SC value-based scorecard and tools to build cause \& effect relationship. The following hypothesizes was developed:

$H_{4}: S C$ value-based scorecard connects value-based metrics with the valuebased SC strategy.

$H_{5}$ : The pyramid performance management model supports the implementation of the hierarchy of SCM value-based metrics. 
4- Research method aspects are applied differently. Some rather theoretical papers give no or few references to industrial companies examples, some papers comprise case studies from one or few companies, and the others papers extensively evaluate several hundreds of observations. In this paper, we use a case-oriented example to illustrate the benefits of the approach and highlight the value of using the hierarchy of SCM value-based scorecard metrics in practice.

\section{A conceptual model for SCM value-based scorecard}

We propose a conceptual model for SCM value-based scorecard that considers the literature on SCM, BSC, and VBM, criteria for selecting performance measures for SC, SCM performance measures, and tools for building the causal relationships between measures to construct performance management for SCM. Figure (1) shows the process of developing a conceptual model with the outcomes for each step leading naturally to the next one. 


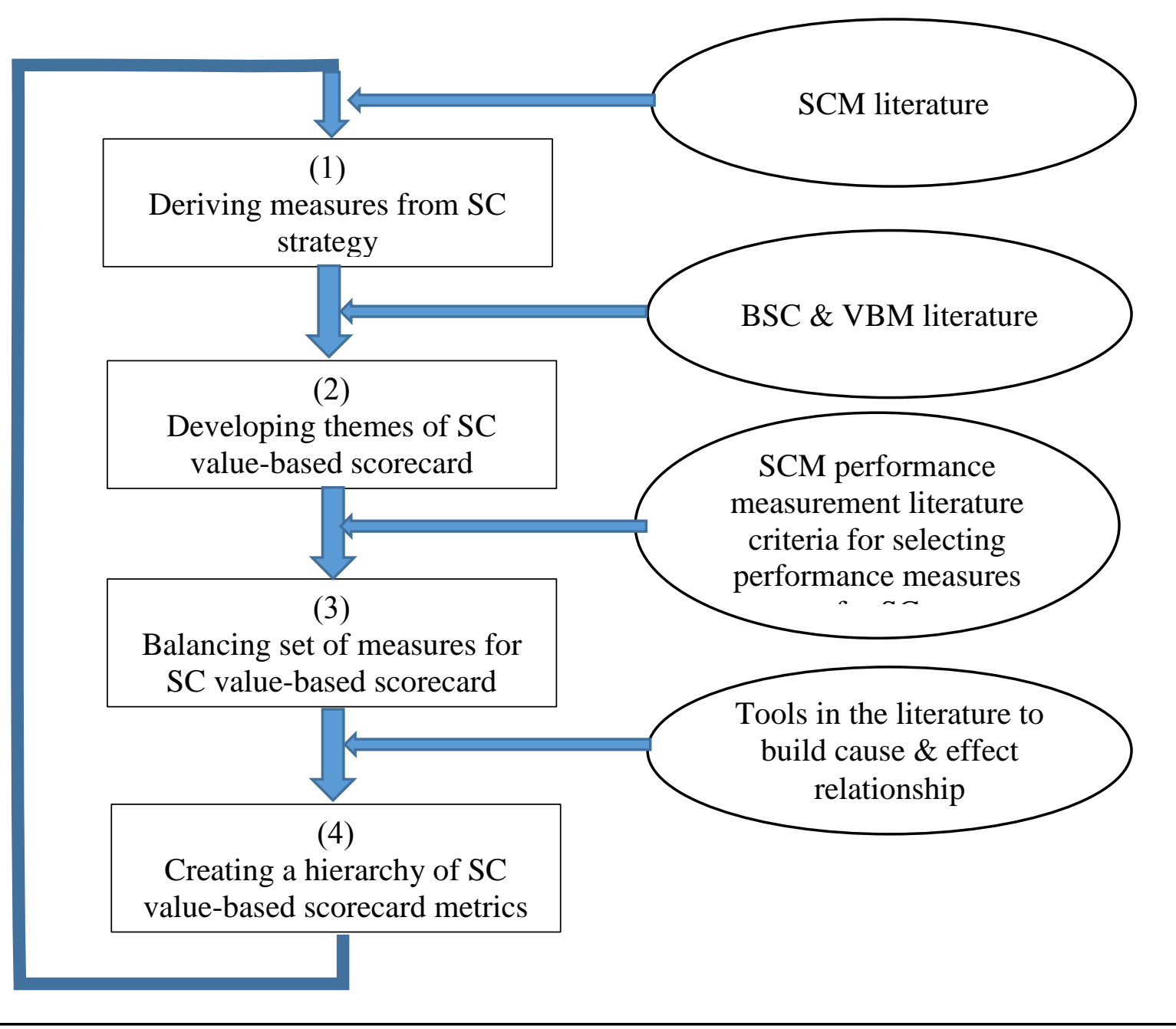

Figure (1) Developing a conceptual model of SCM value-based scorecard

\subsection{Deriving measures from SC strategy}

(Fisher 1997) Classified SCM into several types, but two of the most influential groups are an efficiency improvement type of SCM and a market response type of SCM. The main subjects of the former SCM are the efficient utilization of facilities, efficient inventory improvement, and the reduction of wages and expenses. This type of SCM is led by manufacturers in many cases and adopted to functional products. As the demand for functional products is stable, forecasting is easy. The life cycle of those products is also long, and the rate of return per product is small.

On the other side, the main subjects of the latter SCM are the reduction of market adaptation cost (the opportunity cost of supply deficit, the price cut and sell with the loss on cost by oversupply, etc.) and the build-up of an operation process which makes for rapid adoption. This type of SCM is led by retailers in many cases and is suited to the product whose demand is 
unstable. The demand of an innovative product is particularly volatile and can hardly foresee. Its life cycle is short, and its rate of return per product is high.

(Gattorna 2006) Criticizes Fisher's model by arguing that a single product may belong to several supply chains because market conditions might change and affect the demand patterns of the product. (lee 2002) Presents a model of four-supply chain strategies based on Fisher's distinction of functional and innovative products. Lee's framework of foursupply chains match's supplies chain uncertainty with demand uncertainty.

Fisher (1997) and Lee(2002) Present that supply chain strategy alignment should make against products, but Gattorna(2006) argues that instead of products, customers are the cornerstone on which supply chain strategy should be formed. Gattorna(2006) introduces the framework of four supply chains, as illustrated in figure (2). The framework classified supply chains according to the predictability of demand and relationship with the customer:

1. Continuous replenishment supply chain includes high predictability of demand and tight relationship with the customer. Focus on customer relationship.

2. Lean supply chain includes high predictability of demand and loose relationship with the customer. However, it does not mean poor service levels, but the focus is on efficiency.

3. Agile supply chain includes little predictability of demand and tight relationship with the customer. Focus on speed and capacity.

4. Fully flexible supply chain includes little predictability of demand and loose relationship with the customer. Focus on creative solutions with the premium price.

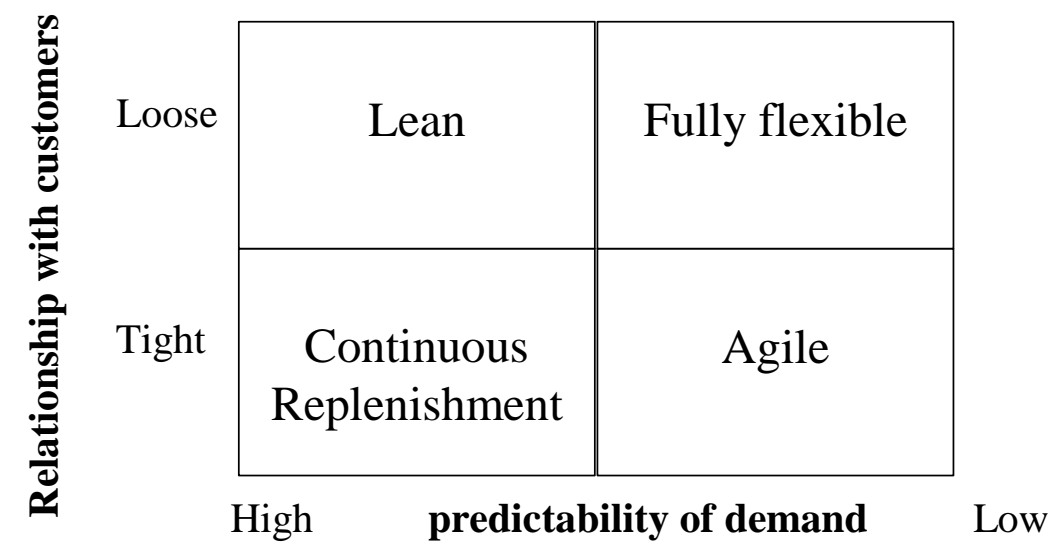

Figure (2) Four generic supply chain types

Source: (Gattorna (2006) p.42) 
Gattorna (2006) suggested that companies should recognize their customer demands through these four supply chains, and select the ones that suit them best. Aligning supply chains according to exact customer needs and expectations improves operating and financial performance for several reasons. It is easier to focus on fulfilling customer requirements and to charge value added based on the supply chain services offered to the customer. Unlike some authors (e.g. Fisher (1997);Lee (2002)), Gattorna(2006) suggests that products and services might belong to several supply chains as demand pattern changes.

Another classification of SC strategy and relevant measures made by (Van Hoek 1998) that suggested the preliminary framework for a supply chain measurement system as in figure (3) was developed. It sheds some first light on the selection of appropriate measures and a measurement approach, depending on the strategic context and operational contribution of players in the supply chain competitiveness. The vertical bar reflects possible contributions of players in the chain to the overall chain competitive. Cost savings, customer services, and overall chain integration are used, as they may reflect fundamental strategies for players in the chain. The horizontal bar reflects the stage of development of logistics in an organization from logistics as a cost-sever to logistics as a set of activities that can contribute to market creation.

The framework may work as follows: when logistics is (still) dominantly used as a cost saver, and the contribution of players is in the area of costs (left bottom segment), appropriate measures may be the part per minute, the percentage of logistics costs as a share of total costs, as traditionally used by suppliers. A retailer that has reached the second stage of market penetration/market extension and emphasis on delivering customer service (middle segment) may benefit from a measurement approach that, instead, uses fill rates and response times. SMART, finally, uses logistics to create new markets, based on an innovative supply chain format (as described above) and is focused on integrating the entire chain (top right segment). Relevant measures used by SMART may be the level of commitment of individual players in the chain and percentage of customization achieved with respect for customer orders and specific activities in the chain.

Van Hoek's model of three supply chain strategies is used as a basic theory in this paper and the SCM value-based scorecard metrics suggested fit the case of SMART SC. 


\section{Contribution of}

players to

supply chain

competitiveness

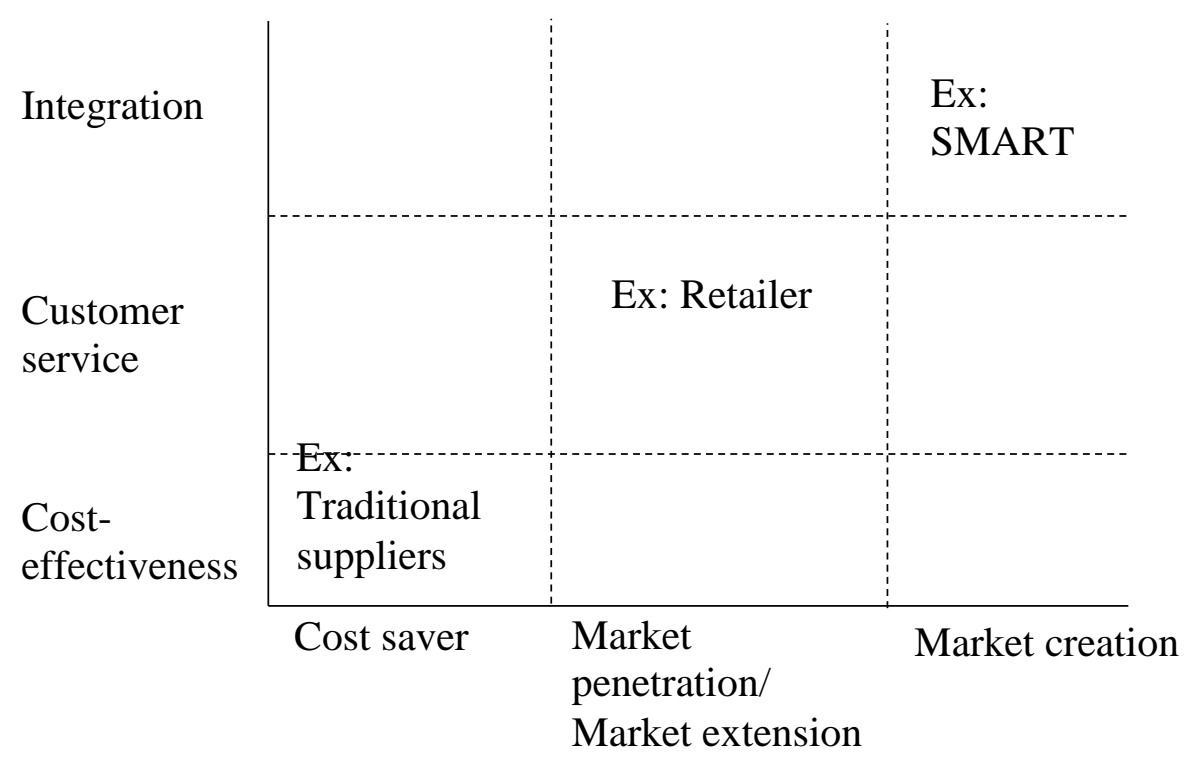

Strategy/Strategic Sophistication

Figure (3) Preliminary framework for a supply chain measurement system

Source: (Van Hoek (1998) P.191)

\subsection{A developing supply chain value-based scorecard structure}

SCM by value-based scorecard is the type of management that considers the interests of all stakeholders and increases the long-term corporate value.

A scorecard makes it possible to substitute or modify individual perspectives (Kaplan and Norton 1992,1993). Based on the value-based framework, this option should exercise. A value perspective should, therefore, integrate to the four common perspectives; it includes the individual components of EVA Momentum and SC value drivers. Furthermore, the financial perspective should be renamed to read "financial and investor perspectives" to reflect the importance of investors in this context Faupel (2012).

In this paper, the researcher uses the "business process perspective" instead of the "internal process perspective" because it is desirable to consider the meaning of process broadly in the case of SCM. The shift in philosophy that takes place when a supply chain point of view is embedded within the balanced scorecard framework is that the internal perspective of the scorecard is expanded to include both the "inter-functional" and "partnership" perspective. In this sense, the value-based scorecard is also not designed for inter-enterprise measurement and therefore has to modify for application in the context of SCM. If the value-based scorecard applies 
to the management of supply chains, it includes inter-enterprise performance measures in addition to the individual enterprise performance measures Hamada (2006).

In addition to the expansion of the four common perspectives of the balanced scorecard (BSC) to adopt to VBM approach and inerorganizational activities, some authors suggest a structure modification by integrating the suppliers as a new perspective into the BSC framework Hamada(2006). Several reasons support this classification between customers and suppliers Ackermann (2007); first, from the superior objective of customer orientation results, activities that lie outside of the defined supply chain entity must consider, especially those of Second-tier and third-tier suppliers; second, for an effective stakeholder management, it seems justified not only for reasons of complexity reduction- to separately regard the interests of upstream and downstream stakeholders; third, major problems of SCM such as complexity, little transparency, and the dynamic can much better be resolved by installing a supplier perspective. While on one hand dynamic environmental changes in the supply chain can be sent upstream more quickly, on the other hand, complexity and little transparency can be attenuated by separately visualizing the cause and effect relationships; finally, implementing a supplier perspective may be advantageous, because the conventional organizational separation of purchasing and sales can better be displayed in the BSC with the corresponding suppliers and customers perspectives. Thus, a differentiated performance evaluation and incentive system design are facilitated.

In conclusion, the following six perspectives construct SCM value-based scorecard structure, as illustrated in figure (4):

1. Financial and investor perspective,

2. Value perspective,

3. Suppliers perspective,

4. Customer perspective,

5. Business process perspective, and

6 . Innovation and learning perspective. 


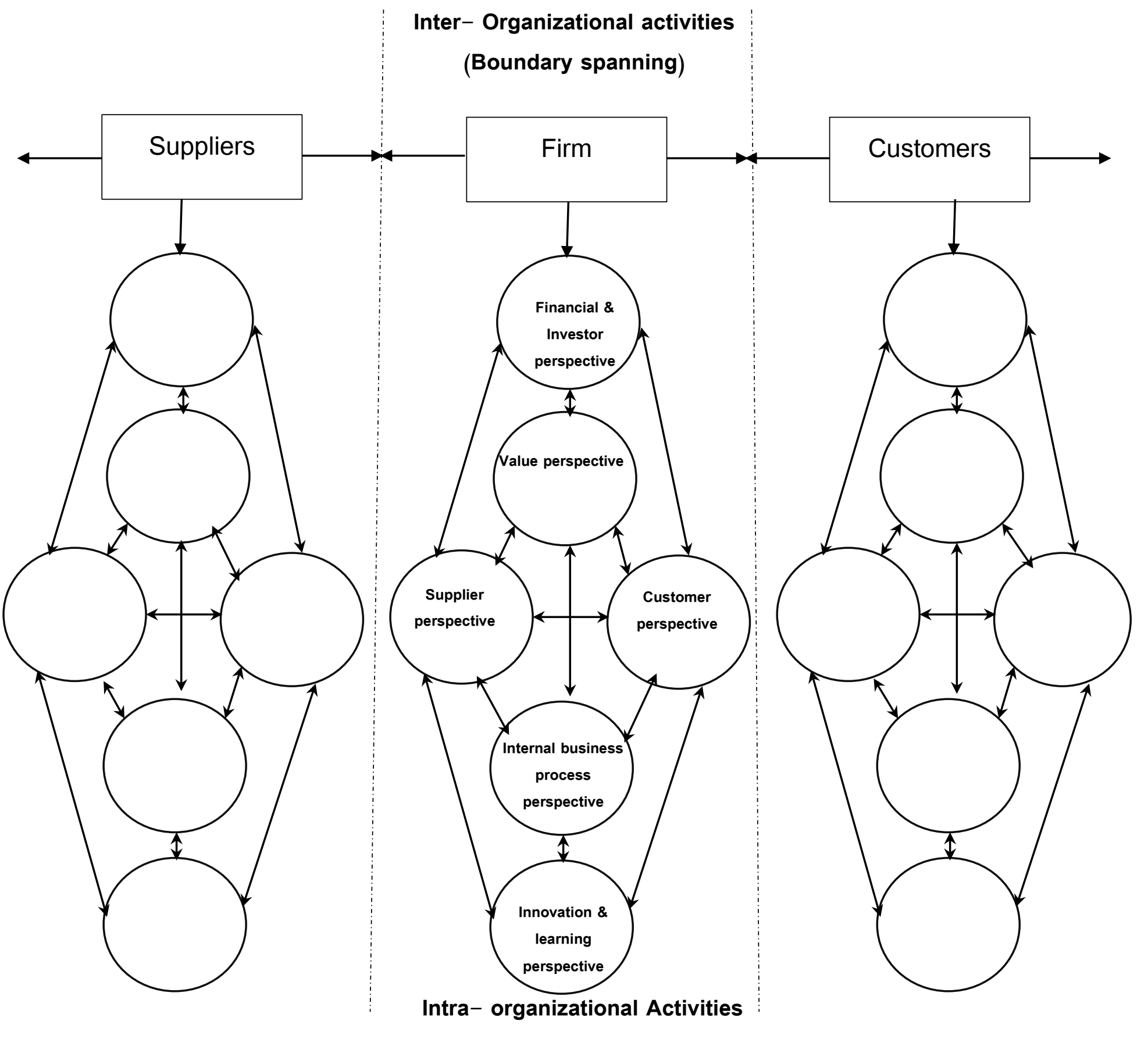

Figure (4) SC value-based scorecard structure

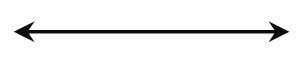

Inter-organizational 
Figure (5) shows the objectives in six perspectives of the SC value-based scorecard. We derive objectives from VBM literature for the financial and investor perspective and value perspective. The financial perspective and investor perspective is composed of three objectives: owner wealth creating, increase share price, and future cash flow generation. The value perspective consists of four objectives: EVA growth, productivity gains, profitable growth, and asset management.

The customer perspective in the BSC consists of the unique mix of product and service attributes, customer relations, and corporate image. By incorporating the features of SCM, the objective of a unique mix of product and service attributes is expanded to improve product leadership, and the objective of customer relations is renamed improve customer relationship (Park et al. 2005). Corporate image is adopted in the SC Value-based scorecard as (Kaplan and Norton 1996) proposed.

The supplier perspective fits the SCM literature, thus, it has differentiated objectives, which consist of three objectives: supplier partnership, improvement of the collaboration in the product development, and improvement of supplier satisfaction.

In the business process perspective, Kaplan and Norton(1996) only mentioned the internal business process. They proposed four categories of objectives: operational management, innovation, customer management, and regularity and social. Since the scope of it are too board, we defined the objectives for the perspective in particular terms.

(Ketchen et al. 2008) highlight speed, quality, cost and flexibility as these key competitive priorities within the "best value supply chains." Specifically, speed is the ability to deliver products or services according to a set schedule while quality is focused on increasing product reliability and customer satisfaction. Flexibility is related to the capacity of a chain to respond to the changing needs of the customers and cost refers to the creation of customer value through expenses reduction or benefits increase at the same cost level.

Balancing of these four priorities can give to the chain the ability to achieve the highest level of total value added to the final customer and the firms involved. Worth nothing that in the mainstream SCM literature these four competitive priorities (speed, quality, cost, and flexibility) are being objectives of SC processes. In the innovation and learning perspective, we adopt of increasing intangible capitals: information sharing, collaboration management, and organizational capital Lee (2000). 


\begin{tabular}{|c|c|c|c|c|c|}
\hline $\begin{array}{l}\text { Financial \& } \\
\text { investor } \\
\text { perspective }\end{array}$ & $\begin{array}{l}\text { Owner wealth } \\
\text { creating }\end{array}$ & & \multicolumn{2}{|c|}{ Share price } & Future cash flow \\
\hline $\begin{array}{l}\text { Value } \\
\text { perspective }\end{array}$ & EVA growth & \multicolumn{2}{|c|}{$\begin{array}{l}\text { Productivity } \\
\text { gains }\end{array}$} & $\begin{array}{l}\text { Profitable } \\
\text { growth }\end{array}$ & $\begin{array}{c}\text { Asset } \\
\text { management }\end{array}$ \\
\hline $\begin{array}{l}\text { Customer } \\
\text { perspective }\end{array}$ & $\begin{array}{l}\text { Customer } \\
\text { relationship }\end{array}$ & & \multicolumn{2}{|c|}{ Product leadership } & Corporate image \\
\hline $\begin{array}{l}\text { Supplier } \\
\text { perspective }\end{array}$ & \multicolumn{2}{|l|}{$\begin{array}{c}\text { Supplier } \\
\text { partnership }\end{array}$} & \multicolumn{2}{|c|}{$\begin{array}{l}\text { Collaboration in } \\
\text { product development }\end{array}$} & $\begin{array}{c}\text { Supplier } \\
\text { satisfaction }\end{array}$ \\
\hline $\begin{array}{l}\text { Business } \\
\text { process } \\
\text { perspective }\end{array}$ & Speed & \multicolumn{2}{|c|}{ Quality } & Cost & Flexibility \\
\hline $\begin{array}{l}\text { Innovation \& } \\
\text { Learning } \\
\text { perspective }\end{array}$ & \multicolumn{2}{|c|}{ Information capital } & \multicolumn{2}{|c|}{$\begin{array}{c}\text { Collaboration } \\
\text { management }\end{array}$} & $\begin{array}{c}\text { Organizational } \\
\text { capital }\end{array}$ \\
\hline
\end{tabular}

Figure (5) objectives in the SCM value-based scorecard perspectives

\subsection{Balancing set of measures for SC value-based scorecard}

There is little evidence that firms have incorporated the value-based scorecard into their SCM practices, so a key goal of this article is to introduce several examples of the types of value-based performance measures that would fit within the $\mathrm{SC}$ value-based scorecard.

(Faldu and Krisbna 2007) refer to address the four essential characteristics that made metrics effective when choosing a particular set of metrics: reliability, validity, accessibility, and relevance. (Hofman 2006) Presents a comprehensive and ongoing measurement program. The author focuses on distinguishing between what it takes to define the metrics your organization will use versus what is needed to implement the measurement process itself. Doing these well will allow companies to improve the dimensions of the performance measurement maturity model and move up the curve.

Brewer and Speh (2001) Pointed that there are a wrong way and a right way to select measures for a balanced scorecard. The wrong way is to use a brief 
brainstorming secession to generate a wealth of potential measures that are quickly assembled disconnected scorecard which will eventually pull different functional managers and supply chain partners in competing directions. The right way is to spend the extra time to ensure that the chosen measures are Harmonized, Optimal, Parsimonious, and Economic (HOPE).

Harmonized measures are connected across the sixth perspectives of the value-based scorecard in a manner that motivates cross-functional managers to focus on complementary objectives. Optimal measures control the risk of motivating employees to overachieve on one dimension of performance while causing suboptimal performance overall from the standpoint of the customer. Parsimony refers to the decision as to how many measures to include in the scorecard. Though there is no "right" number, the goal should be to create a scorecard that is complete. That means the scorecard should motivate goal-congruent performance but do so with the fewest possible measures. A measure that cannot be connected to other measures within the scorecard should be dropped. Each measure must either work harmony with other measure or help control for the risk sub-optimal performance. Furthermore, any measure that is highly correlated with another measure within the scorecard is a candidate for exclusion. Generally speaking, fewer measures (12 to 24) are preferable to more measures ( 25 or more). Helping managers stay focused on the most important dimensions of performance.

Economic measures offer value by driving optimal performance that exceeds the related data-gathering costs. Some measures with a large appeal, in theory, have prohibitive data gathering costs. Therefore, when discussing measures that are candidates for inclusion in a scorecard, companies need to address the question of data availability. For measures deemed critically important, it may make sense to invest in the technology necessary to support the data- collection effort. In other situations, it may make sense to track a modified version of the measure that is less costly regarding data availability.

The list is not necessarily exhaustive; rather, it is intended to help fuel a discussion about value-based performance measurement that is clearly in its infancy. Many of the measures in the SC value-based scorecard may be unfamiliar see tables from (2) to (7).

What makes these measures seem foreign is that they focus on behaviors and situations that contradict the arm's length business practices that characterize most firm's long history of operating as a singular entity in uncoordinated transactional relationships. We used an ordinary group of value outcomes that could apply to all chain members and to supply chains of different products. 
Table (2) Measures for financial \& Investor perspective

\begin{tabular}{|c|c|c|c|}
\hline Measures & Definition & Benefits & Source \\
\hline $\begin{array}{l}\text { Market value Added (MVA) } \\
\text { MVA }=\mathrm{MV} \text {-capital or } \\
\mathrm{MVA}=\sum_{t=0}^{T} N P V(E V A)\end{array}$ & $\begin{array}{l}\text { The spread between the } \\
\text { market's valuation of the } \\
\text { business, given its share } \\
\text { price and the capital } \\
\text { invested in it or equal the } \\
\text { present value of the EVA } \\
\text { profit that a firm can be } \\
\text { expected to earn in the } \\
\text { future. }\end{array}$ & $\begin{array}{l}\text { The MVA expansion } \\
\text { indicates that the firms are } \\
\text { now adding, even more, } \\
\text { value, is creating, even more, } \\
\text { wealth, has enlarged its } \\
\text { franchise value, and has } \\
\text { beefed up the corporate NPV } \\
\text { larder, compared to the prior } \\
\text { year. }\end{array}$ & $\begin{array}{l}\text { Stewart } \\
(2013)\end{array}$ \\
\hline $\begin{array}{l}\text { MVA Spread } \\
=\text { MVA/capital }\end{array}$ & $\begin{array}{l}\text { This measure quantifies } \\
\text { the relative size of the } \\
\text { firm`s MVA. }\end{array}$ & $\begin{array}{l}\text { It is a wealth creating } \\
\text { efficiency ratio. It is an } \\
\text { improved version of the price } \\
\text { - to - book ratio that avoids } \\
\text { accounting distortions and } \\
\text { leverage vagaries. }\end{array}$ & $\begin{array}{l}\text { Stewart } \\
(2013)\end{array}$ \\
\hline MVA Margins =MVA/Sales & $\begin{array}{l}\text { It is the ratio of franchise } \\
\text { value per dollar of } \\
\text { revenue. }\end{array}$ & $\begin{array}{l}\text { It measures the efficiency } \\
\text { with which the company is } \\
\text { translating customer } \\
\text { satisfaction into owner } \\
\text { wealth. }\end{array}$ & $\begin{array}{l}\text { Stewart } \\
(2013)\end{array}$ \\
\hline $\begin{array}{l}\text { Free cash flow }(\mathrm{FCF})= \\
\text { NOPAT- } \Delta \text { Capital } \\
\text { FCF generation }= \\
(\text { FCF/Capital })\end{array}$ & $\begin{array}{l}\text { FCF makes it possible for } \\
\text { companies to make an } \\
\text { interest payment, pay off } \\
\text { the principal on the } \\
\text { loans, pay dividends, and } \\
\text { buy back shares. These } \\
\text { are the four ways that } \\
\text { companies return cash to } \\
\text { their capital providers, } \\
\text { and therefore, the } \\
\text { expectations of such cash } \\
\text { flows will be the ultimate } \\
\text { determinate of a } \\
\text { company s value from a } \\
\text { capital market } \\
\text { perspective. }\end{array}$ & $\begin{array}{l}\text { Because investments tie up } \\
\text { cash, their value is based on } \\
\text { the amount of future cash } \\
\text { flow that will accrue to } \\
\text { investors. FCF can be } \\
\text { thought of as the amount of } \\
\text { cash flow left over from the } \\
\text { company s operating } \\
\text { activities after expected } \\
\text { investments have been made. } \\
\text { It is from this residual cash } \\
\text { flow; companies can then } \\
\text { return cash to their capital } \\
\text { providers. }\end{array}$ & $\begin{array}{l}\text { Young and } \\
\text { O'Byrne } \\
(2001)\end{array}$ \\
\hline
\end{tabular}


Table (3) Measures for value perspective

\begin{tabular}{|c|c|c|c|}
\hline Measures & Definition & Benefits & Source \\
\hline $\begin{array}{l}\text { EVA measure } \\
\text { EVA=NOPAT- capital } \\
\text { charge }\end{array}$ & $\begin{array}{l}\text { It is the difference between } \\
\text { net of profit after tax and } \\
\text { capital charge }\end{array}$ & $\begin{array}{l}\text { It is just a money measure of } \\
\text { economic profit. }\end{array}$ & $\begin{array}{l}\text { Stewart } \\
(2013)\end{array}$ \\
\hline $\begin{array}{l}\text { EVA Momentum (EVA } \\
\text { growth rate) } \\
=\Delta \mathrm{EVA} / \text { prior sales }\end{array}$ & $\begin{array}{l}\text { It measures the growth rate } \\
\text { in EVA, scaled to sales. }\end{array}$ & $\begin{array}{l}\text { It is the one ratio measure that } \\
\text { completely and correctly } \\
\text { summarizes the total } \\
\text { performance of business in all } \\
\text { ways that it can add value or } \\
\text { subtract from it. } \\
\text { Partners in SC will certainly } \\
\text { benefit from having one EVA } \\
\text { Momentum ratio metric to } \\
\text { legitimately sit at the very top } \\
\text { of all these performance } \\
\text { scorecards. } \\
\text { EVA Momentum is a statistic, } \\
\text { but this one has real meaning. } \\
\text { Any positive EVA Momentum } \\
\text { is good because that means } \\
\text { EVA has increased; any } \\
\text { negative EVA momentum is } \\
\text { bad, for them EVA has } \\
\text { decreased, and Zero EVA } \\
\text { Momentum is a true breakeven. }\end{array}$ & $\begin{array}{l}\text { Stewart } \\
(2013)\end{array}$ \\
\hline $\begin{array}{l}\text { EVA margins = } \\
\text { EVA / Sales or } \\
\text { Productivity gains }\end{array}$ & $\begin{array}{l}\text { It is the percentage of sales } \\
\text { that falls to the EVA bottom } \\
\text { line after deducting all } \\
\text { operating and capital costs. } \\
\text { It is firm's true economic } \\
\text { profit margin. }\end{array}$ & $\begin{array}{l}\text { It is a key summary measure of } \\
\text { profitability and productivity } \\
\text { consolidating operating } \\
\text { efficiency and asset } \\
\text { management in a reliable and } \\
\text { comparable net margin score. } \\
\text { EVA margin quite simply takes } \\
\text { the mission of maximizing } \\
\text { value and turns it into a sales- } \\
\text { based margin framework. }\end{array}$ & $\begin{array}{l}\text { Stewart } \\
\text { (2013) }\end{array}$ \\
\hline $\begin{array}{l}\text { Profitable growth }= \\
{[(\text { EVA/sales }) \times \text { sales }} \\
\text { growth }]\end{array}$ & $\begin{array}{l}\text { It measures the value added } \\
\text { from profitable sales } \\
\text { growth. }\end{array}$ & $\begin{array}{l}\text { That precisely quantifies how } \\
\text { much value was added from } \\
\text { delivering quality growth, and } \\
\text { conveniently expresses it on the } \\
\text { same scale as productivity gains } \\
\text { so that visualizing the trade-offs } \\
\text { is a lot easier. }\end{array}$ & $\begin{array}{l}\text { Stewart } \\
(2013)\end{array}$ \\
\hline
\end{tabular}


Table (4) Measures for supplier perspective

\begin{tabular}{|c|c|c|c|}
\hline Measures & Definition & Benefits & Source \\
\hline $\begin{array}{l}\text { Supply chain total cost of } \\
\text { ownership }\end{array}$ & $\begin{array}{l}\text { The total cost of } \\
\text { ownership (TCO) is a } \\
\text { method of calculating the } \\
\text { total cost of acquiring } \\
\text { goods and services from a } \\
\text { supplier. TCO includes } \\
\text { not only the purchase } \\
\text { price but also the costs of } \\
\text { any other activities } \\
\text { associated with the } \\
\text { supplier relation. The list } \\
\text { examples of these } \\
\text { additional activity costs } \\
\text { include purchasing } \\
\text { activity costs, receiving } \\
\text { activity costs, and failure } \\
\text { activity costs. }\end{array}$ & $\begin{array}{l}\text { It provides evidence on } \\
\text { whether the logistics } \\
\text { processes throughout the } \\
\text { chain are wasteful or } \\
\text { inefficient. It is best analyzed } \\
\text { by the component of cost. It } \\
\text { is necessary to evaluate this } \\
\text { measure relative to historical } \\
\text { performance or ideal } \\
\text { standards. Accountants can } \\
\text { develop a TCO index for } \\
\text { evaluating supplier total cost } \\
\text { performance. The index is } \\
\text { the TCO per unit divided by } \\
\text { the purchase price per unit. } \\
\text { Some firms use the index to } \\
\text { adjust supplier price bids. } \\
\text { TOC analysis rewards } \\
\text { excellent supplier behavior } \\
\text { and penalizes poor behavior. } \\
\text { Occuring when managing } \\
\text { supply chain relations } \\
\text { beyond price. }\end{array}$ & $\begin{array}{l}\text { (Reeve, } \\
\text { 2005) }\end{array}$ \\
\hline $\begin{array}{l}\text { The number of order } \\
\text { configurations offered } \\
\text { relative to response time }\end{array}$ & $\begin{array}{l}\text { The measure is a ratio that } \\
\text { relates how effectively the } \\
\text { suppliers can provide } \\
\text { variety to its customers } \\
\text { (regarding pallet patterns, } \\
\text { skulls, and so on) without } \\
\text { unduly lengthening the } \\
\text { time it takes to create this } \\
\text { variety. }\end{array}$ & $\begin{array}{l}\text { Combining the number of } \\
\text { choices with a response time } \\
\text { is necessary because it is not } \\
\text { useful only to measure the } \\
\text { number of order } \\
\text { configurations alone; } \\
\text { providing a huge variety } \\
\text { usually, translates into longer } \\
\text { cycle time or much higher } \\
\text { cost. The suppliers of SC } \\
\text { can both increase variety and } \\
\text { decrease cycle time will have } \\
\text { a distinct advantage. }\end{array}$ & $\begin{array}{l}\text { Brewer and } \\
\text { Speh (2000) }\end{array}$ \\
\hline $\begin{array}{l}\text { The resource (component) } \\
\text { category commitment } \\
\text { ratio }\end{array}$ & $\begin{array}{l}\text { The numerator of the ratio } \\
\text { captures the percentage of } \\
\text { the supplier's total } \\
\text { resource category sales } \\
\text { that one sold to a } \\
\text { particular customer. The } \\
\text { denominator captures the }\end{array}$ & $\begin{array}{l}\text { It can be analyzed from two } \\
\text { different perspectives; first, it } \\
\text { measures the extent to which } \\
\text { suppliers partnerships indeed } \\
\text { exist; second, it assesses the } \\
\text { potential risk to which each } \\
\text { supplier is exposed within a }\end{array}$ & $\begin{array}{l}\text { Brewer and } \\
\text { Speh }(2000)\end{array}$ \\
\hline
\end{tabular}




\begin{tabular}{|l|l|l|l|}
\hline & $\begin{array}{l}\text { percentage of that } \\
\text { customer's resource } \\
\text { category needs that they } \\
\text { brought from that } \\
\text { supplier. }\end{array}$ & supply chain relationship. & \\
\hline $\begin{array}{l}\text { The number of shared data } \\
\text { sets with suppliers } \\
\text { relatives to total data sets }\end{array}$ & $\begin{array}{l}\text { Information sets sharing } \\
\text { such as demand forecasts, } \\
\text { advance shipping notices, } \\
\text { production schedules } \\
\text { strategic directions and } \\
\text { trust and customer targets } \\
\text { must be shared with } \\
\text { suppliers to realize fully } \\
\text { the potential inherent in } \\
\text { inter-organizational } \\
\text { integration and teamwork. }\end{array}$ & $\begin{array}{l}\text { SCM precepts suggest that } \\
\text { information sharing is vital } \\
\text { to the success of SC } \\
\text { partnerships. }\end{array}$ & $\begin{array}{l}\text { Brewer and } \\
\text { Speh (2000) }\end{array}$ \\
\hline
\end{tabular}

Table (5) Measures for customer perspective

\begin{tabular}{|c|c|c|c|}
\hline Measures & Definition & Benefits & Source \\
\hline $\begin{array}{l}\text { Number of customer } \\
\text { contact points }\end{array}$ & $\begin{array}{l}\text { It is a measure of service } \\
\text { quality that captures how } \\
\text { many people the customer } \\
\text { has to interact with to be } \\
\text { served. }\end{array}$ & $\begin{array}{l}\text { The theoretical ideal is a } \\
\text { single contact point all the } \\
\text { way back through the supply } \\
\text { chain. When numerous } \\
\text { possible contact points exist } \\
\text { at each link in the supply } \\
\text { chain, the potential for } \\
\text { miscommunication waste, } \\
\text { and delayed response } \\
\text { increases exponentially. }\end{array}$ & $\begin{array}{l}\text { Brewer and } \\
\text { Speh }(2000)\end{array}$ \\
\hline $\begin{array}{l}\text { Relative customer order } \\
\text { response time }\end{array}$ & $\begin{array}{l}\text { It can be used to compare } \\
\text { the time it takes one } \\
\text { supply chain to respond to } \\
\text { a customer order to the } \\
\text { time it takes a competing } \\
\text { SC to answer to a } \\
\text { comparable order. }\end{array}$ & $\begin{array}{l}\text { The benchmark used in } \\
\text { conjunction with this } \\
\text { measure can also be } \\
\text { ambitious world-class } \\
\text { standard rather than a } \\
\text { competing SC. }\end{array}$ & $\begin{array}{l}\text { Brewer and } \\
\text { Speh (2000) }\end{array}$ \\
\hline $\begin{array}{l}\text { Customer value ratio } \\
(\mathrm{CVR})=\text { survey measure } \\
\text { cost per order }\end{array}$ & $\begin{array}{l}\text { The focus on value } \\
\text { relative to cost is the } \\
\text { distinguishing feature of } \\
\text { this type of performance. }\end{array}$ & $\begin{array}{l}\text { The intent of the SC would } \\
\text { be to increase this ratio by } \\
\text { increasing customer } \\
\text { satisfaction (the numerator) } \\
\text { or decreasing unit cost (the } \\
\text { denominator). }\end{array}$ & $\begin{array}{l}\text { Dummer et } \\
\text { al. }(2015)\end{array}$ \\
\hline $\begin{array}{l}\text { Supply chain cost volume } \\
\text { ratio }(\mathrm{SCCR})= \\
\quad \text { Net sales }- \text { total SCC }\end{array}$ & $\begin{array}{l}\text { It is not good for this ratio } \\
\text { to be negative or close to }\end{array}$ & $\begin{array}{l}\text { Using SCCR as a measure to } \\
\text { compare with other SC }\end{array}$ & $\begin{array}{l}\text { (Pettersson } \\
\text { and } \\
\text { Segerstedt }\end{array}$ \\
\hline
\end{tabular}




\begin{tabular}{|l|l|l|l|}
\hline Net sales & $\begin{array}{l}\text { zero, if it remains so far } \\
\text { along time, the existence } \\
\text { of the activity is in } \\
\text { danger. If net sales } \\
\text { decrease, total SCC } \\
\text { should also decrease, and } \\
\text { if net sales increased total } \\
\text { SCC will in most cases } \\
\text { also increase. }\end{array}$ & $\begin{array}{l}\text { makes little sense because } \\
\text { SC has products with } \\
\text { different values and costs } \\
\text { and different sales volumes. } \\
\text { The ratio SCCR may be } \\
\text { comparable to various } \\
\text { products, plants and markets } \\
\text { within the same SC. The } \\
\text { best and most reasonable } \\
\text { comparison is with is self } \\
\text { over time. }\end{array}$ & 2013) \\
& & & \\
\hline
\end{tabular}

Table (6) Measures for business process perspective

\begin{tabular}{|c|c|c|c|}
\hline Measures & Definition & Benefits & Source \\
\hline $\begin{array}{l}\text { Total supply chain cost } \\
\text { (SCC) }\end{array}$ & $\begin{array}{l}\text { It made up of the } \\
\text { following components: } \\
\text { direct purchasing cost, } \\
\text { manufacturing operating } \\
\text { cost, transportation cost, } \\
\text { warehouse operating cost, } \\
\text { inventory holding cost } \\
\text { and customer service } \\
\text { operating cost. }\end{array}$ & $\begin{array}{l}\text { It is important to emphasize } \\
\text { that these track the } \\
\text { performance of the entire } \\
\text { SC. It is necessary to } \\
\text { evaluate this measure } \\
\text { relative to historical } \\
\text { performance or ideal } \\
\text { standards. }\end{array}$ & $\begin{array}{l}\text { Pettersson } \\
\text { and } \\
\text { Segerstedt, } \\
(2013)\end{array}$ \\
\hline $\begin{array}{l}\text { The SC cycle efficiency } \\
\text { measure = } \\
\text { Total value added time } \\
\text { Total time in the SC }\end{array}$ & $\begin{array}{l}\text { The goal is to progress } \\
\text { toward the ideal measure } \\
\text { of } 1.00 \text {, which indicates } \\
\text { that non-value added time } \\
\text { does not exist in the SC. }\end{array}$ & $\begin{array}{l}\text { Often a significant source of } \\
\text { wasted time is the "hand- } \\
\text { off" between organizations. } \\
\text { This measure helps expose } \\
\text { those sources. Also, this type } \\
\text { of cycle efficiency measure } \\
\text { can be calculated by each } \\
\text { functional department across } \\
\text { SC to pinpoint where } \\
\text { problems lie or where } \\
\text { functional efficiencies can be } \\
\text { gained. }\end{array}$ & $\begin{array}{l}\text { Brewer and } \\
\text { Speh }(2000)\end{array}$ \\
\hline $\begin{array}{l}\text { The number of choices } \\
\text { offered relative to } \\
\text { response time }\end{array}$ & $\begin{array}{l}\text { If the SC offers } 20 \\
\text { different order } \\
\text { configurations and the } \\
\text { order cycle time is four } \\
\text { days, the ratio is } 20 / 4=5\end{array}$ & $\begin{array}{l}\text { This measure implies that } \\
\text { SC should strive to increase } \\
\text { the ratio, either by offering } \\
\text { more variety at the same or } \\
\text { lower response time or by } \\
\text { providing the same level of } \\
\text { choice at a reduced response } \\
\text { time. }\end{array}$ & $\begin{array}{l}\text { Brewer and } \\
\text { Speh }(2000)\end{array}$ \\
\hline $\begin{array}{l}\text { The percentage of } \mathrm{SC} \\
\text { target costs }\end{array}$ & It can be used to ensure & Calculating these types of & Brewer and \\
\hline
\end{tabular}




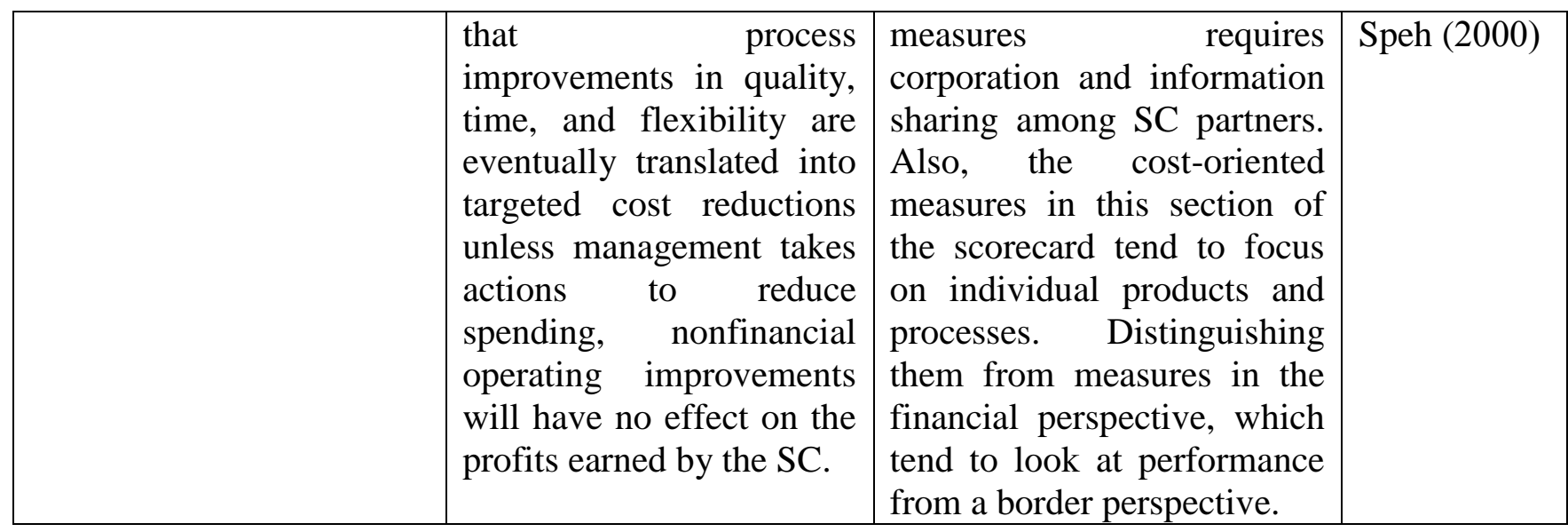

Table (7) Measures for innovation \& learning perspective

\begin{tabular}{|c|c|c|c|}
\hline Measures & Definition & Benefits & Source \\
\hline $\begin{array}{l}\text { The product finalization } \\
\text { point }\end{array}$ & $\begin{array}{l}\text { It addresses the } \\
\text { increasingly important } \\
\text { issue of postponement. } \\
\text { The underlying premise of } \\
\text { postponement is that } \\
\text { creating finished goods } \\
\text { that are not immediately } \\
\text { sold commits an } \\
\text { organization's resources, } \\
\text { which increases the } \\
\text { likelihood that it will } \\
\text { experience stock-outs and } \\
\text { markdowns. }\end{array}$ & $\begin{array}{l}\text { The goals is to push final } \\
\text { product completion as close } \\
\text { to the final customer as } \\
\text { possible to reduce } \\
\text { inventories and minimize the } \\
\text { risk of unsold product. The } \\
\text { way to manage } \\
\text { postponement is to create } \\
\text { product or process } \\
\text { innovations that enable a } \\
\text { supply chain to reduce the } \\
\text { time elapsed between } \\
\text { finalization and customer } \\
\text { delivery. }\end{array}$ & $\begin{array}{l}\text { Brewer and } \\
\text { Speh (2000) }\end{array}$ \\
\hline $\begin{array}{l}\text { The product category } \\
\text { commitment ratio }\end{array}$ & $\begin{array}{l}\text { The numerator of the ratio } \\
\text { captures the percentage of } \\
\text { the seller's total product } \\
\text { category sales that are } \\
\text { sold to a particular } \\
\text { customer. The } \\
\text { denominator captures the } \\
\text { percentage of that } \\
\text { customer's product } \\
\text { category needs that they } \\
\text { brought from that seller. }\end{array}$ & $\begin{array}{l}\text { This measure can be linked } \\
\text { to others in the scorecard, } \\
\text { such as EVA margin by } \\
\text { supply chain partner to } \\
\text { provide convincing evidence } \\
\text { regarding the extent to which } \\
\text { real partnerships exist } \\
\text { throughout the SC. }\end{array}$ & $\begin{array}{l}\text { Brewer and } \\
\text { Speh (2000) }\end{array}$ \\
\hline $\begin{array}{l}\text { The number of shared data } \\
\text { sets relative to total data } \\
\text { sets }\end{array}$ & $\begin{array}{l}\text { It can be used to } \\
\text { encourage SC partners to } \\
\text { create a common } \\
\text { language for managing } \\
\text { various processes. }\end{array}$ & $\begin{array}{l}\text { It indicates whether } \\
\text { additional opportunities are } \\
\text { present for sharing relevant } \\
\text { data sets when each firm } \\
\text { uses its own terminology to }\end{array}$ & $\begin{array}{l}\text { Brewer and } \\
\text { Speh (2000) }\end{array}$ \\
\hline
\end{tabular}




\begin{tabular}{|c|c|c|c|}
\hline & & $\begin{array}{l}\text { identify parts, it generates } \\
\text { other data that only create } \\
\text { confusion and inefficiency } \\
\text { and a lack of inter- } \\
\text { organizational harmony. }\end{array}$ & \\
\hline $\begin{array}{l}\text { The performance } \\
\text { trajectories of competing } \\
\text { technologies measure }\end{array}$ & $\begin{array}{l}\text { The intent of measuring } \\
\text { this measure is to help a } \\
\text { supply chain ensure that } \\
\text { its products both current } \\
\text { and future generations are } \\
\text { not supplanted by an } \\
\text { emerging technology that } \\
\text { went undetected until it } \\
\text { was too late. }\end{array}$ & $\begin{array}{l}\text { A measure is useful for SC } \\
\text { because each partner needs } \\
\text { to understand how the } \\
\text { technologies underlying its } \\
\text { activities add value for the } \\
\text { ultimate customer. If a } \\
\text { threatening technology has } \\
\text { the potential to attract a } \\
\text { supply chain's customers, } \\
\text { then this awareness needs to } \\
\text { be communicated throughout } \\
\text { the SC. So the appropriate } \\
\text { partners can respond by } \\
\text { advancing the capability of } \\
\text { the suitable process or } \\
\text { product technology to ensure } \\
\text { the SC remains competitive } \\
\text { and retains its customers. }\end{array}$ & $\begin{array}{l}\text { Brewer and } \\
\text { Speh (2000) }\end{array}$ \\
\hline
\end{tabular}

\subsection{Creating the hierarchy of SCM value-based scorecard metrics}

There are clearly many important metrics but it's also clear that they are not all equal, nor do they stand independently of each other. Which are the ones that matter? And what should you do with them once you have them?

We use the pyramid performance management model suggested by lynch and Cross (1995) and Hofman (2004) (2007) as a tool to develop what we call the hierarchy of SC value-based metrics to bring order to the chaos. The hierarchy is the three-tiered framework that gives managers a progressively more granular view of their performance. Each of the three levels of the hierarchy shown in figure (6) serves the different purpose and aimed at the different goal.

The top level allows an executive to assess, with just three metrics, the overall health of the supply chain and the high-level trade-offs a company might be making. The next level of detail uses a composite Customer-Value Ratio (CVR) to provide an initial diagnostic tool. And the third level uses a variety of metrics that support effective root causes analysis and allow highly efficient and precise corrective actions. Let's look at each in detail. 
Top Tier: assess; at the highest level are three key metrics: EVA Momentum, productivity gains, and profitable growth. EVA Momentum sits at the top level because it's a measure of total performance progress.

Inching down from the top level; in figure (6), the first step is to divide EVA Momentum into two main components, from which all other performance factors can be derived. The first is about running smarter, and the second is about running faster. The first one is called "productivity gains" and it comes from generating an increase in the EVA Margin. The second is called "profitable growth," a multiplicative factor that comes from delivering positive sales growth at a positive EVA Margin (or from cutting back on sales that carry a negative EVA Margin) Stewart (2013).

Figure (6) The hierarchy of SC value-based SC metrics

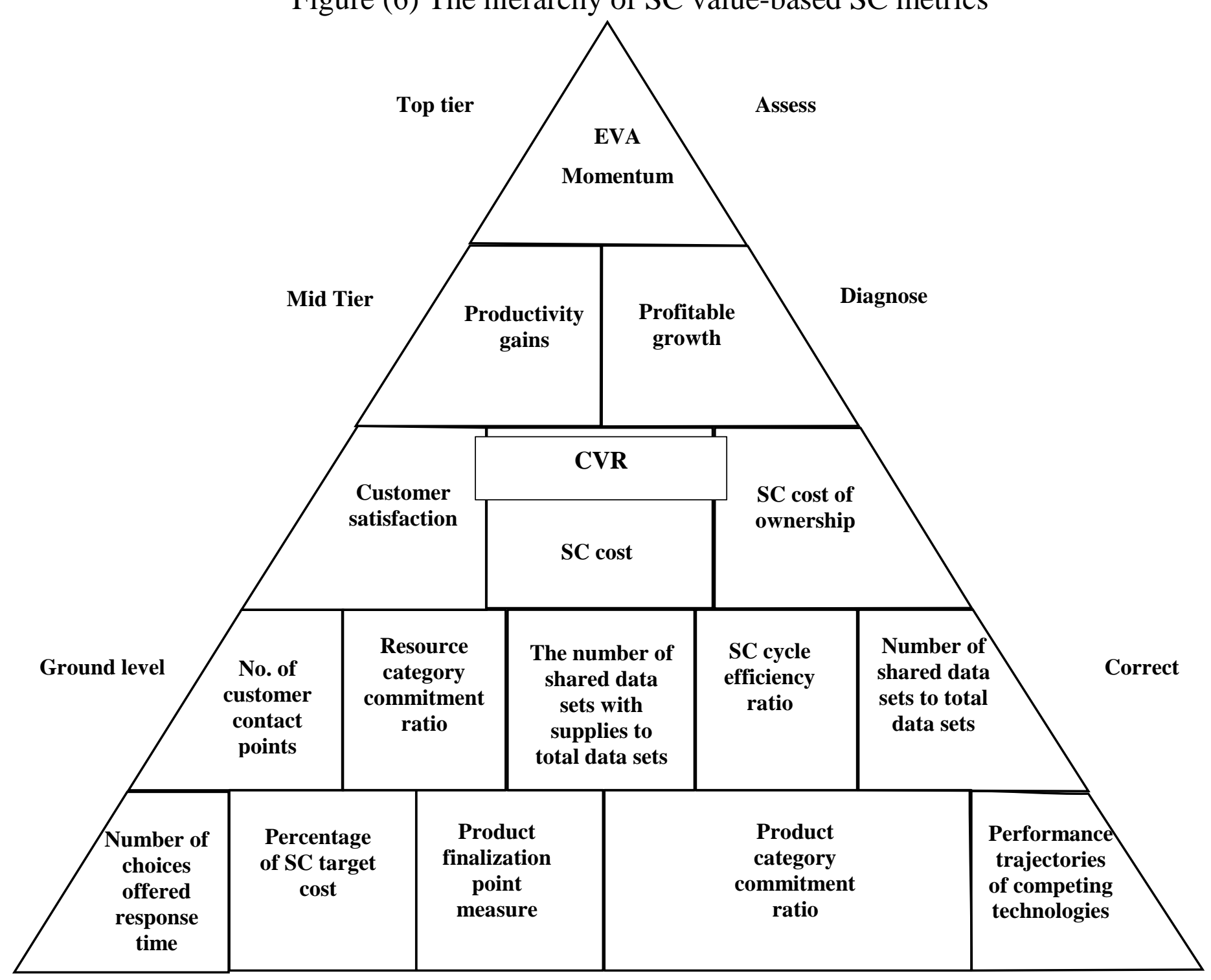


Let's take a closer look at the productivity gains $=\Delta$ (EVA/Sales). It is the value added by increasing the EVA-to-Sales ratio and from driving more EVA to the bottom line out of top-line sales. It is the value added from tuning up the business engine, expanding the EVA margin, and enhancing the business model productivity through some combination of what I like to call the "3-p's" standing for the price, product, and process.

Yücesan (2016) illustrated that from a strategic perspective, the supply chain manager should be responsible for customer service levels, which, in turn, are driven by product, process, and supply chain design choices. The choices made in configuring the supply chain will have a direct impact on fixed assets. The product and process design decisions, in turn, will become constraints on operational drivers that will affect both expenses and working capital requirements.

That says that EVA margin expansion can come from learning and exerting sales power, such as; through leveraging brand, innovation or service, or just getting prices right. Also, it can come from improving the product mix by putting an outsourcing, (all-stars EVA- positive product line up on the field and benching products, and features, and customers that are not EVA positive). Also, it can come from process excellence, from running a tight, lean, efficient ship from top to bottom, through operations excellence and asset management, and even covering taxes, restructuring investments, acquisition pricing discipline, and integration success as critical processes to manage. Note, though; it does take an improvement in the EVA margin to propel EVA Momentum. Just sustaining excellence processes on holding on to a full gross margin would only maintain the current margin and would not add momentum, at least not in this category. It takes real productivity progress to increase EVA and to drive EVA momentum because EVA momentum measures performance at the margin and is the news in the data.

The other main EVA momentum category measures the value added from profitable sales growth that precisely quantifies how much value was added from delivering quality growth and conveniently expresses it on the same scale as productivity gains so that visualizing the trade-offs is a lot easier.

Clearly, an advantage of this format is that it enables a manager or analyst to accurately summarize the value added and dependable rank the performance progress of what may be very different business plans. For example, it puts the value added from an improving turnaround story on precisely the same analysis footing as would apply to a growth star. It is analysis method suitable for all business missions. 
Mid Tier: diagnose; the next level looks at Customer-Value Ratio (CVR). This critical metric not only allows a company to see how well it's managing customer but also facilitates analysis of the components that tell what's happening deeper in the supply chain. The CVR is a composite metric that includes customers, suppliers, and business process measures. It lets managers see whether there's the trade-off between customer satisfaction and cost per order.

This metric also indicates whether the components of SC total cost or SC total cost of ownership, which can contribute to the high cost per unit and deserve further analysis. High cost per unit might be a result of low SC cycle efficiency ratio, low response time for suppliers, the low percentage of SC target cost and low response time for customers. Each of these components is a symptom of a different underlying problem.

Only after looking at the four metrics in the hierarchy's top two tiers does it make sense to drive into more detailed metrics to find ways to correct any problems uncovered at the top. Instead of attempting to wade through the chaos of 24 metrics at the start, the hierarchy allows you to begin with just four and use what is uncovered there to guide your path through the remaining metrics.

Ground level: correct; analyzing the detailed metrics at the ground level reveals the root causes of high SC total cost, or high SC cost of ownership, or poor customer satisfaction. Once the cause is identified, managers can design and implement the interventions that will correct it with the most efficient use of resources.

The SC value-based scorecard metrics has a portfolio of operational metrics. Metrics at the ground level include supplier effectiveness indicators. These indicators include the number of resources (components) relative to response time and the resources (components) category commitment ratio as well as the number of shared data sets with suppliers relative to total data sets that are often the effect on supplier performance.

Other ground-level metrics are those that indicated an SC business processes effectiveness. Among these are the SC cycle efficiency, the number of choices offered relative to response time, and the percentage of supply chain target costs. Other ground-level metrics focus on inter-organizational innovation and learning which include the product finalization point measure, the product category commitment ratio, the number of shared data sets relative to entire data sets, and the performance trajectories of competing technologies measure. 


\section{The Hierarchy of SCM value- based scorecard metrics in practice: A case- oriented example ${ }^{1}$}

\section{4-1 Background of a case-oriented example}

Let a fictitious company a manufacturer of household products. It is a large company with many different products. The company is divided into different product areas each with it is an own profit and loss responsibility. The company's controlled supply chain consists of order handling, purchasing, production, distribution and support functions. The supply flow is customer-order driven.

External partners perform two parts in the supply chain, another company does production; company $\mathrm{B}$, and distribution by a delivery service provider; company C. Order handling receives and takes care of the customer orders and places purchase orders with production is done by a core company. The people at orders handling also initiate the shipment at the distribution service provider. Support functions take care of follows and contacts with the supplier.

Company's business strategy is to be the most cost efficient than its competitors while keeping market response off SC or bar. An examination of its supply chain metrics reveals that its performance accurately reflects this business strategy as illustrated in figure (7). However, the company has some specific opportunities to share its external relationships with suppliers, customer's logistics providers, and partners- in real target ways. By doing so, a company can continue to foster its market response while keeping costs of supply chain down. Accomplishing that; it is helpful to look at each of the tiers in greater detail.

\section{4-2 Analysis each of the tiers}

Assess: Trading efficiency improvement for the market response. Looking at Consumer Company's top tier, you can see its productivity gains are real while its profitable growth is negative. Consistent with its strategy, this company is focused on refining of market response but is doing so at the expense of the cost efficient improvement. As is shown in the Table (8) let's starts with the money measures, and then build into the new ratio metrics.

\footnotetext{
${ }^{1}$ It is impossible for the SCM value-based scorecard to be described in detail and broken down to individual members firms of the supply chain the strategic goals attainable measures of total supply chain, except when the total supply chain are executed by a firm. Therefore, we consider the applied study as follows: the case of supply chain members collaborates and that own firms arranged by a core firm. In this case, the total performance of supply chain has measured by the core firm, but details are entrusted to each firm.
} 


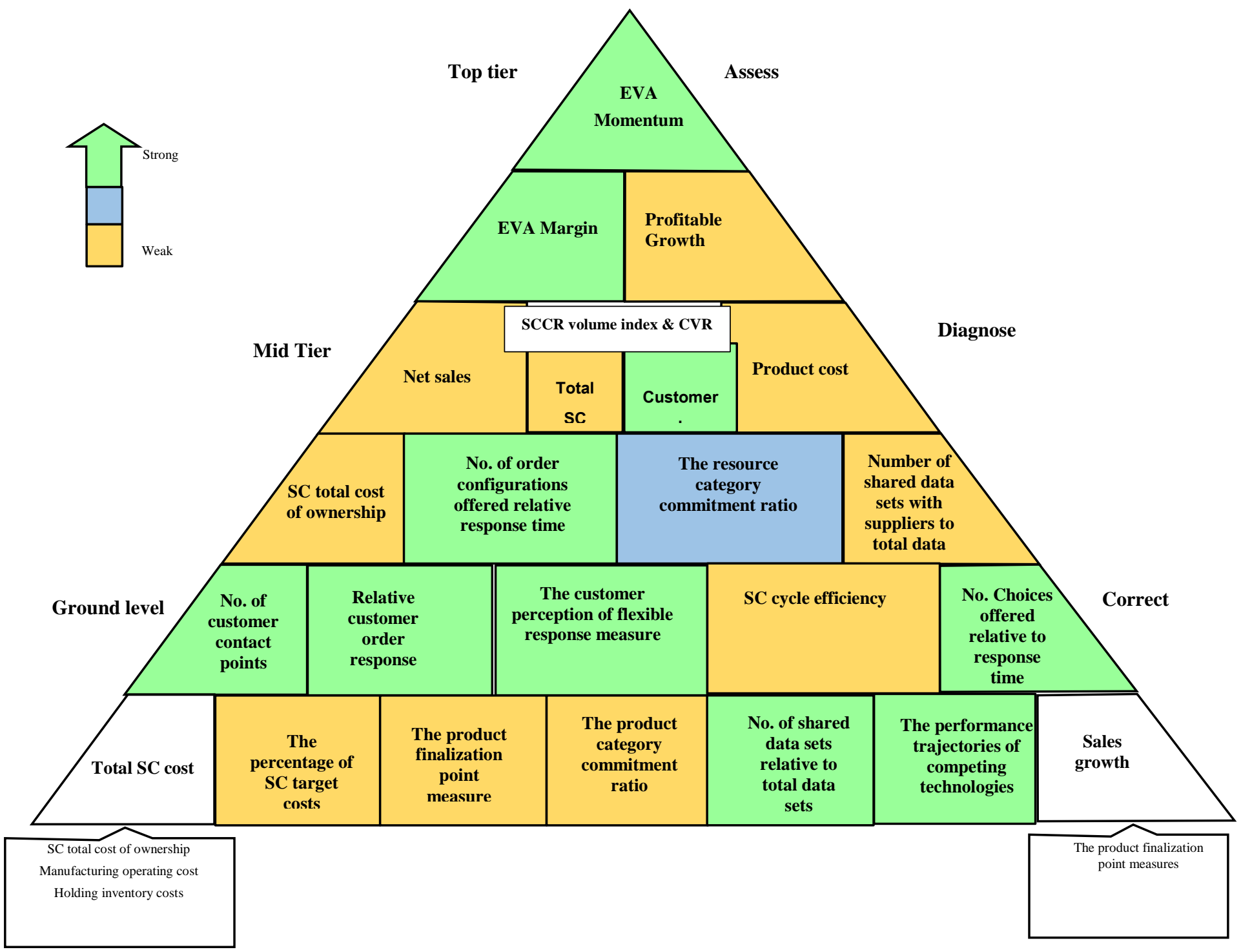

Figure (7) Hierarchy of value-based scorecard metrics for the case example 
Table (8) Summary value-based scorecard metrics for the case example

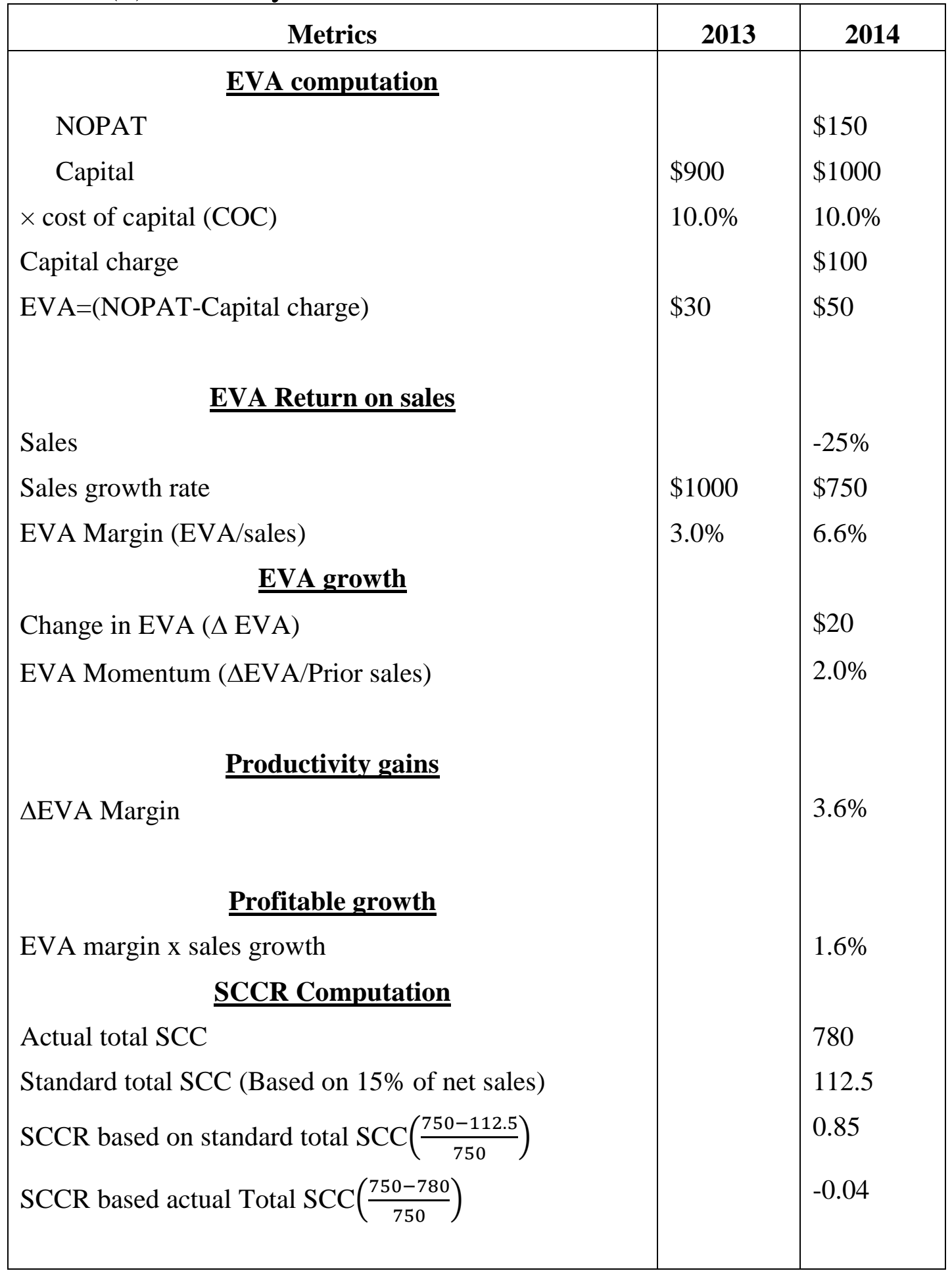

The company generated an EVA of $\$ 50$ in its most recent year. Without showing the details, let's assume that the consumer company's EVA was $\$ 30$ in the prior year, as shown on the table. 
These basic facts tell us two important things about the company right off the bat: it is profitable, and it improved, as EVA increased from $\$ 30$ to $\$ 50$. But how significant a performance is that? Let's size-adjust the money measures to find out. Start with the EVA margin. I have assumed that the company's sales were $\$ 1.000$ in the first year and $\$ 750$ the next year. Do the math. The EVA/sales profit margin was $\$ 30 / \$ 1.000$ or 3 percent the first year and $\$ 50 / \$ 750$ or 6.6 percent the next year.

It is an impressive improvement in performance productivity, to be sure and we'll see where it comes from latter but that statistic understates the true extent of the firm's overall performance in the year. Total performance progress is measured by EVA momentum, which is the $\$ 20$ increase in EVA divided by the $\$ 1.000$ sale base in the prior year. The firm's EVA Momentum was 2 percent in the most recent year, as shown on the table. The next question is: how did that happen? What were performance factors responsible?

It shows that a multiplicative factor of the EVA Momentum comes from delivering negative sales growth at a positive EVA margin. It means that 3.6 percent of consumer co.'s EVA Momentum came from getting better and -1.6 percent came from negative sales growth or decline to 2 percent because of negative sales growth.

The company achieves more productivity gains and doesn't have profitable growth or running smarter but don't run faster. As for the example company, it declined 25 percent to its sales and earned a 6.6 percent in EVA margin, a combination that contributed to -1.6 percent to its EVA momentum. That precisely quantifies how much value was added or detracted from delivering quality growth, and conveniently expresses it on the same scale as productivity gains so that visualizing the trade-offs is a lot easier.

As for consumer co., we can see at a glance that the firm generated a significant increase in its economic profit and the first section of the value added came from making the business engine run better, with more torque and spark. The other part of detracting value come from do not run faster than the growth in productivity gains is only detracting from its decline in sales growth or loss ratio in sales growth. EVA margin at a negative sales growth will only dig a deeper hole.

The first commandment must be to improve the sales growth. Get bigger after you get better. Go on more races after you become better. Repair the partnership's management, do what it takes to move an incrementally positive sales growth rate for the supply chain.

Diagnose: supply chain cost volume ratio (SCCR) and CVR. At the mid-tier, the difference between SCCR computation based on actual total SCC and standard total SCC is significant. 
The SCCR measurement based on actual cost presented an SCCR of -0.04 and based on calculated standard costs, and a margin $15 \%$ of net sales presents an SCCR of 0.85. The difference between these two measurements is significant. Meaning that it looks like the business is doing well. SCCR based on actual cost shows that the SCC is higher than net sales. Meaning that the SCC has to be reduced or net sales have to be increased to make the SC profitable.

The study led to a complete reorganization of the supply chain work, with fewer people involved. The significant finding from this study is that if the standard costs used are too tight, the right information about the SCC will not observe. Therefore, the company may use its resources inefficiently, and it will create disadvantages, and it will not be possible to see whether the product or (customer) is profitable or not.

The company may have inadvertently assigned too many people and resources to be involved in the supply chain. The cost is observed somewhere else in the company. If the product should carry its own cost then the number of people and poorly understood right from the beginning, the supply chain may be wrongly composed. The greatest danger is that people within the organization may make wrong decisions because they have inadequate information.

Looking at the second metric at the mid-tier, Mathematically, the customer value index is created by dividing the customer value assigned to each of the product's features by the features cost.

Product feature that has a value index below one are targets for cost reduction, whereas features with a value index above one are candidates for additional investment. See the table (9) for a specific product.

\begin{tabular}{|c|ccc|}
\hline Features of product & Customer value score & Product costs & Value Index \\
\hline Feature 1 & $4.4 \%$ & $6.0 \%$ & 0.73 \\
Feature 2 & $4.0 \%$ & $8.0 \%$ & 0.50 \\
Feature 3 & $51.3 \%$ & $22.0 \%$ & 2.57 \\
Feature 4 & $14.5 \%$ & $17.0 \%$ & 0.85 \\
Feature 5 & $7.0 \%$ & $14.0 \%$ & 0.50 \\
Feature 6 & $4.7 \%$ & $10.0 \%$ & 0.47 \\
Feature 7 & $4.8 \%$ & $19.0 \%$ & 0.25 \\
Feature 8 & $4.7 \%$ & $4.0 \%$ & 1.18 \\
Feature 9 & $4.5 \%$ & $2.0 \%$ & 2.25 \\
Totals & $100.0 \%$ & $100.0 \%$ & \\
\hline
\end{tabular}

Table (9) Value index (Entire product) 
In the studied product example, the value index for the feature 7 , is 0.25 , which means its customer value score is considerably below its cost. Therefore, it is a good candidate for cost reduction. Conversely, at 2.57, the customer value score for the feature 3 is much high than its cost. Thus, the manufacturer may actually choose to enhance or upgrade the feature 3 to better satisfy customer requirements. A perfectly aligned matrix would have a value index of one for each relationship.

Correct: Trading partner opportunities. At the ground level, deeper root causes analysis uncovers specific suppliers, business process, customers, and innovation $\&$ learning areas that need corrective actions.

Supplier relationships: Consumer Co. has supply chain cost of ownership that is higher than historical performance. Providing evidence on the logistical processes throughout the chain are wasteful or inefficient, and it is best analyzed by the components of cost, such as total warehousing costs or total expediting cost, or by activity such as purchasing activity costs or receiving activity costs rather than by aggregating all costs into one number. An examination of the number of shared data sets with suppliers relative to total data sets reveals the lower number of shared data sets with suppliers. Information sets such as demand forecasts, advance shipping notice, production schedules, strategic directions and trust, and customer targets must be shared among supply chain partners to realize fully the potential inherent in intra-organizational integration and framework. When each firm uses its terminology to identify components parts, it generates additional data that only create confusion and inefficiency and a lack of inter-organization harmony.

Internal business process relationships: looking at the components of total supply chain cost uncover one potential source of the higher SC cost. The supply chain cycle efficiency equals 0.2 percent . The goal is to progress toward the ideal measure of 1.00 which indicates that none value added times does not exist in the supply chain. Often a significant source of wasted time is the "hand-off" between firms. As this metric relate to SC costs, we can look at the related SC cost details. Consistent with its high total SC costs, consumer co.'s manufacturing operating costs are very bad, at 4 percent higher than the average.

At the same time streamlining a process by process improvements in quality, time, and flexibility does not translate into targeted cost reduction. In other words, it creates additional idle capacity. Also, the percentage of SC target costs tend to focus on targeted cost reductions for individual products and processes.

Inter-organizational innovation and learning: The correct action that improves the total SC costs might also help improve the product finalization point measure. Consumer co.' inventory holding costs are higher than the average by 3 percent. 
One possibility is that it might be the last product competition doesn't close to the final customer so high inventories and maximize the risk of unsold product.

The way to manage postponement is to create product or processes innovations that enable a supply chain to reduce the time elapsed between finalization and customer delivery. From the perspective of the product category commitment ratio, ratio less than 1.0 indicate the imbalance of power and commitment between supply chain partners, and the level of risk grows. This type of imbalance may be indicated that one partner could use its leverage to extract additional financial benefits from the relationship at the expenses of another partner. This measure can be linked to others in the scorecard, such as EVA margin by SC partner to provide convincing evidence regarding the extent to which right partnerships exist throughout the supply chain.

Using the hierarchy provides a focused means to assess, diagnose, and correct a company's supply chain health. It enables efficient root-cause analysis by clearly highlighting the problem areas and their interdependencies, providing a way to trace any issue to its source through an increasingly granular focus.

\section{4-3 Developing and prioritizing action items}

What a successful analysis of themes, interdependencies, and tradeoffs reveals is where the levers are in your supply chain. The appropriate action items and their priorities then naturally emerge. In this case example, we define three categories of prioritization:

- Immediate focus: these areas present the greatest opportunity and potential benefit from improvements. These are often cause levers which, if fixed, will have a significant positive impact on other performance areas. Examples here include improvement to the total SCC or net sales.

- Raise the bar: there are additional areas where improvements can be realized. Current performance in these areas may be adequate, but the area is important enough to a company's particular strategy and business goals that improving performance is worthwhile. For example, the resource category commitment ratio is primary business goal, performance on this metric should be brought up a notch.

- Monitor and revisit: these areas will likely be impacted by improvements in the cause problem areas identified in "immediate focus," and therefore do not require immediate action themselves. Including, for example, SC total cost of ownership that is a result of supplier performance issues or total SCC that is a result of SC cycle efficiency. On the supplier and business processes sides, the first order of business for the case example is to investigate further the primary reasons for its poor supply and internal 
processes performance and determine how much of it, if any, is due to high SC target costs.

Right on the heels of that should be an implementation of a consistent supplier and internal processes performance measurement program with scorecards to make performance readily visible and easy to address.

\section{Summary and Conclusions}

Valid measurement of SCM in the context of the BSC and VBM has become more important. The paper gives answers to two research questions; (1) how to build SCM value-based performance measurement model with a balanced metric system? (2) How to implement suggested SCM value based scorecard approach? The extent to which these questions can be answered by current research which is assessed by closer study of these works revealing four challenges issues that can be fundamental to the development of a new measurement approach and construct our proposed methodology in the paper. First, the SCM approach in the paper emphasized on the concept of how well a group of companies performs regarding value creation for the customers and shareholders. Second, the paper choices the EVA momentum metric as a new measure helping to eliminate many of the limitation associated with traditional EVA measure. Third: selecting value drivers are consistent with maximizing shareholder value for the supply chain as a whole and this could be within an adapted "value-based scorecard" framework. Fourth: the paper uses the pyramid performance management model as a tool to bring order to the chaos and support the implementation of the new measurement approach. This tool answers two questions: which are the ones that matter? And what should you do with them once you have them?

The conceptual model for SCM value-based scorecard considers the literature on SCM, BSC, and VBM and consists of four sequential steps with the outcomes for each step leading to naturally to the next step. Step (1): deriving measures from SC strategy, the paper adopted the type of SMART supply chain strategy that uses logistics to create new markets and focused on integrating the entire supply chain. Step (2): developing themes of SC value-based scorecard, which constructed from six perspectives. A value perspective incorporated in addition to the four standard perspectives of BSC. The shift in philosophy that takes place when a supply chain point of view is embedded within the BSC framework is that the internal perspective of the scorecard is expanded to include both the "inter-functional" and partnership" perspective. Thus, in this paper, we used the "business process perspective" instead of the "internal process perspective." Also, supporting the classification between customers and suppliers, the paper suggested a structure modification by integrating suppliers as a new perspective on the SCM valuebased scorecard themes. We develop objectives for each perspective in SCM value-based scorecard that fit the value orientation concept. Step (3): balancing set 
of measures for SCM value-based scorecard perspectives. This action aims to introduce several examples of the types of value-based performance measures that would fit within the SC value-based scorecard perspectives. We have derived the SCM value-based scorecard measures by merging the measures from the corporate level BSC with measures derived from SCM and VBM literature. Step (4): creating the hierarchy of SCM value-based scorecard metrics. The hierarchy has consisted of a three-tiered framework; each one serves the different purpose. The top tier allows assessing the overall health of the SC and the high-level tradeoffs a company might be making. The mid-tier uses a composite measure to provide an initial diagnostic tool. The ground tier uses a variety of metrics that support efficient root causes analysis.

We analyze the causal relationships between the three-tiered of the hierarchy of SCM value-based scorecard using a case-oriented example. We conclude that what a successful analysis of themes, interdependencies, and tradeoffs reveals is where the levers are in the SC. The appropriate action items and their priorities then naturally emerge. In the case example, we define three categories of prioritization: immediate focus, raise the bar, and monitor and revisit.

The study has two limitations. We use a pyramid performance management model as a systemic method for prioritizing measures. Recently, there have been attempts to augment it by combining it with decision-making tools such as analytic hierarchy processing (AHP) or fuzzy ratios. Furthermore, the caseoriented example adopts the case that firms of supply chain members collaborate and that own firm is arranged by a core firm. Ideally, the realistic case is that a core company does not exist. In this case, it is useful for all SC members to make out value-based scorecard based on strategic themes from the view of the total supply chain because each member can know how it can contribute to the total supply chain performance.

Two interesting questions that future studies could use quantitative models such as Data Envelopment Analysis (DEA) models in creating benchmarking based on value-based scorecard measures which may contribute to directing management's effort in optimizing the supply chain efficiency. Second, do empirical studies of the factors influencing the success or failure of an attempt to implement SCM value-based scorecard approach. 


\section{References}

- Ackerman, I. (2007), Using the balanced scorecard for supply chain management - Prerequisites, Integration Issues, and Performance Measures. In Hopper T., Northcott D., and Scapens, R. (Editors), Issues in Management Accounting ( $3^{\text {rd }}$ ed) (pp.290-302), Dorchester; Financial Times, prentice Hall.

- Anderson L. D., Britt F. F., and Favre J. D. (2007), Principles of supply chain management, Supply Chain Management Review, April, 41-46.

- Baurratt, M. (2004), Understanding the meaning of collaboration in the supply chain, Supply Chain Management: An International Journal, 9(1): 30-42.

- Beamon, B. M. (1999), Measuring supply chain performance, International Journal of operations \& production Management, 19(3): 275-292.

- Biddle, G.C., Bowen R.M. and Wallace, J. S. (1999), Evidence on EVA, Journal of Applied Corporate Finance, 12/2, 69-80.

- Brandenburg, Marcus, (2013), Quantitative models for value-based supply chain management, New York, USA: Springer, (Chapter 2).

- Brewer, P. C., Chandra, G. and Hock, C. A. (1999), Economic value added (EVA): its uses and limitations, SAM Advanced Management Journal, 64/2, 4-8.

- Brewer, C. P., Speh W. T. (2000), Using the balanced scorecard to measure supply chain performance, Journal of Business Logistics, 21(1): 75-93.

- Brewer C. P., and Speh W. T. (2001), Adapting the balanced scorecard to supply chain management, Supply Chain Management Review, March/April, 48-56.

- Christopher, M., and L. Ryals, (1999), Supply chain strategy: Its impact on shareholder value, International Journal of Logistics Management 10(1): 1-10.

- Dekker H., Groot T., Schoute M. and Wiersman E. (2012), Determinants of the use of value-based performance measures for managerial performance evaluation, Journal of Business Finance \& Accounting, 39(9) \& (10): 12141239.

- Dummer W., Masters M., and Swrenson D., (2015), Delivering customer value through value analysis, Journal of Cost Management, March/April: 17-24.

- Elgazzar S., S. Tipi N., Hubbard N. J. and Leach D. Z. (2012), Linking supply chain processes' performance to a company's financial strategic objectives, European Journal of Operational Research, 223: 276-289.

- Ellinger A., Shin H., Northington W. M., Adams F.G., Hofman D. and O'Marah K. (2012), The influence of supply chain management competency on customer satisfaction and shareholder value, Supply Chain Management: An International Journal, 17/3: 249-262.

- Faldu, T. and Krisbna S. (2007), Supply chain metrics that measure up, Supply \& Demand Chain Executive, April/May: 50-53.

- Faupel, C. (2012), Value-based performance management, Advances in Management Accounting, 20: 187-208. 
- Fisher, M.L. (1997) What is the right supply chain for your product, Harvard Business Review, 75(2), March-April: 105-116.

- Gattorna, J. (2006) Living supply chains, Pearson prentice Hull, Great Britain, (Chapter 2).

- Gunasekaran A., and Koobu B. (2007), performance measures and metrics in logistics and supply chain management: a review of recent literature (199952004) for research and application, International Journal of Production Research, 45 (12): 2819-2840.

- Gunasekaran A., Patel C. and Tirtirouglu E. (2001), Performance measures and metrics in a supply chain environment, International Journal of Operations \& Production Management, 21(1/2): 71-87.

- Guansekaran A., Patel. C. and McGaughey E. R. (2004), A framework for supply chain performance measurement, International Journal of Production Economics, 87: 333-347.

- Hamada, K. (2006), Managerial roles of financial and non-financial measures In supply chain and engineering chain management. In Monden Y., Miyamoto K., Hamada k., Lee G. and Asada T. (Editors), Value-Based Management of the Rising Sun (pp.301-328), Institute of Management: Japanese Management and International studies vol. 1.

- Van Hoek R.I. (1998), Measuring the unmeasurable - measuring and improving performance in the supply chain, Supply Chain Management: An International Journal, 3(4): 187-192.

- Hofman D. (2004), The Hierarchy of supply chain metrics, Supply Chain Management Review, September: 29-37.

- Hofman D. (2006), Getting to world-class supply chain measurement, Supply Chain Management Review, 10/7: 1-18.

- Hofman D. (2007), Supply chain measurement: Turning Data into action, Supply Chain Management Review, November: 20-26.

- Hofmann, E., and A. Locker (2009), Value-based performance measurement in supply chain: A case study from the packaging industry, Production Planning and Control, 20(1): 68-81.

- Ittner, C. -D., and Larcher, D.-F. (2001), Assessing empirical research in managerial accounting: A value-based management perspective, Journal of Accounting and Economics, 32(1-3): 349-410.

- Jack L. (2011), Inter-organizational performance measurement practices between supply chain partners: Issues for the agri-food industry, in Abdel-kader M.G., Review of Management Accounting Research (pp. 749-496), UK, Palgrave Macmillan.

- Jensen, M.- C. (2002), Value maximization, stakeholder theory, and the corporate objective function, Business Ethics Quarterly, 12(1): 235-256. 
- Kaplan, R. S., and Norton, D.-P. (1992). The balanced scorecard: Measures that drive performance. Harvard Business Review, 70 (1): 71-79.

- Kaplan, R. S., and Norton, D.-P. (1993). Putting the balanced scorecard to work. Harvard Business Review, 71 (1): 134-147.

- Kaplan, R. S., and Norton, D.-P. (1996). The balanced scorecard: Translating strategy into action, Boston, MA: McGraw-Hill Professional, (Chapter 3,4).

- Ketchen J.D., Rebarick W., Hult M.G.T., and Meyer D. (2008), Best value supply chains: A key competitive weapon for the $21^{\text {st }}$ century, Business Horizons, 51: 235-243.

- Lambert, M. D., and R. Burduroglu (2000), Measuring and selling the value of logistics, International Journal of Logistics Management, 11(1): 1-17.

- Lambert, M. D., and T. Pohlen (2001), Supply chain metrics, International Journal of Logistics Management, 12(1): 1-19.

- Lasch, R., A. Lemke, and T. Schindler. (2006), The contribution of logistics to value-based management, in N. Schweickart and A. Topfer (Editors), ValueBased Management (pp.271-300), Berlin: Springer

- Lee, H. L. (2000), Creating value through supply chain integration, Supply Chain Management Review, September/October: 30-36.

- Lee, H. L. (2002), Aligning supply chain strategies with product uncertainties, California Management Review, 44(3), Spring: 105-119.

- Lee, H. L. (2004), The Triple-A supply chain, Harvard Business Review, October: 102-112.

- Losbichler, H., and M. Rothböck (2006), Creating shareholder Value through Value-driven supply chain management, in W. kersten and T. Blecker(Editors), Managing risks in supply chains-How to build reliable collaboration in logistics (pp.281-296), Berlin: Erich Schmidt Verlag.

- Lynch R.L. and Cross K. F. (1995), Measure up! Yardsticks for continuous Improvement, Cambridge, USA: Blackwell Publishers Inc., (Chapter 5).

- Monden, Y. (2006), Business value, Human assets, and Organizational restructuring, In Monden Y., Miyamoto K., Hamada K., Lee G. and Asada T. (Editors), Value-Based Management of the Rising Sun (pp.3-16), Institute of Management: Japanese Management and International studies vol. 1.

- Möller K. (2003), Supply chain value-value creating in and by supply chain network, In W. Stölzle and A. Otto (Editors), Supply chain management accounting in theory and practice (pp.49-82), Wiesbaden: Gubler.

- Otto, A., and Obermaier, R. (2009), How can supply networks increase firm value? A causal framework to structure the answer, Logistics Research: 131-148.

- Park H. J., Lee K. J., and Yoo S. J. (2005), A framework for designing the balanced supply chain scorecard, European Journal of Information Systems, 14: 335-346. 
- Pettersson I.A. and Segerstedt A., (2013), Measuring supply chain cost, Int. J. production Economics, 143: 357-363.

- Presutti D. W. and Mawhinney R.J. (2007), The supply chain-finance link, Supply Chain Management Review, September: 32-38.

- Ramanathan V., Gunasekaran A. and Subramanian N. (2011), Supply chain collaboration performance metrics: A conceptual framework, Benchmarking: An International Journal, 18(6): 856-872.

- Rappaport, A. (1996), Creating shareholder value: The new standard for business performance, New York, free press, (Chapter 1).

- Reeve M. J. (2005), Logistics and marketing costs In Weil L. R. \& Maher W. M., John (Editors), Handbook of cost Management (pp.329-349), Second Edition, Hoboken, New Jersey.

- Riceman, S.-S., Cahan, S.-F, and Lal, M. (2002), Do managers perform better under EVA bonus schemes? The European Accounting Review, 11(3): 537-572.

- Shepherd C. and Gunter H. (2006), Measuring supply chain performance: current research and future directions, International Journal of Productivity and performance Management, 55(3/4): 242-258.

- Srivastava, R. K., Shervani, T.A. and Fahey, L. (1999), Marketing, business processes and shareholder value: an organizationally embedded view of marketing activities and the discipline of marketing, Journal of Marketing, 63, special issue: $168-179$.

- Stewart G.-B. (2009), EVA momentum: The one ratio that tells the whole story, Journal of Applied Corporate Finance, 21(2): 74-86.

- Stewart G.-B. (2013), Best-Practice EVA: The definitive guide to measuring and maximizing shareholder value, New Jersey, John Wiley \& Sons, (Chapter 5).

- Tyndall G., Gopal C., Partsch W. and Kamauff J. (1998), Supercharging supply chains: New ways to increase value through global operational excellence, New York: John Wiley \& Sons, Inc., (Chapter 2).

- Walters, D. (1999), The implications of shareholder value planning and management for logistics decision making, International Journal of Physical Distribution and Logistics Management, 29(4): 240-258.

- Young, S.-D., and O’Byrne, S. F. (2001), EVA® and value-based management: A practical guide to implementation, New York: McGraw-Hill, (Chapter 2,7).

- Yücesan E. (2016), Competitive supply chains: A value-based management perspective, Second Edition, New York, Polgrave Macmillan, (Chapter 2). 